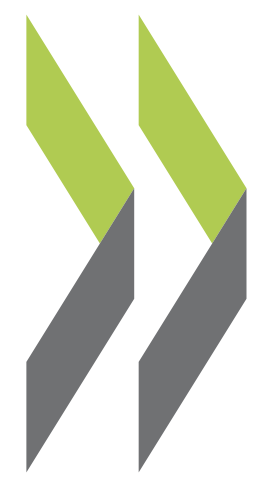

OECD Economics Department Working Papers No. 1510

Enhancing dynamism in SMEs

and entrepreneurship

in Korea
Randall S. Jones, Jae Wan Lee 


\section{ENHANCING DYNAMISM IN SMES AND ENTREPRENEURSHIP IN KOREA ECONOMICS DEPARTMENT WORKING PAPERS No. 1510}

\section{Randall S. Jones and Jae Wan Lee}

OECD Working Papers should not be reported as representing the official views of the OECD or its member countries. The opinions expressed and arguments employed are those of the author(s).

Authorised for publication by Álvaro Pereira, Director, Country Studies Branch, Economics Department.

Document available in pdfformat only.

All Economics Department Working Papers are available at www.oecd.org/eco/workingpapers.

JT03436813 
OECD Working Papers should not be reported as representing the official views of the OECD or of its member countries. The opinions expressed and arguments employed are those of the author(s).

Working Papers describe preliminary results or research in progress by the author(s) and are published to stimulate discussion on a broad range of issues on which the OECD works.

Comments on Working Papers are welcomed, and may be sent to OECD Economics Department, 2 rue André-Pascal, 75775 Paris Cedex 16, France, or by e-mail to eco.contact@oecd.org.

All Economics Department Working Papers are available at www.oecd.org/eco/workingpapers.

This document and any map included herein are without prejudice to the status of or sovereignty over any territory, to the delimitation of international frontiers and boundaries and to the name of any territory, city or area.

The statistical data for Israel are supplied by and under the responsibility of the relevant Israeli authorities. The use of such data by the OECD is without prejudice to the status of the Golan Heights, East Jerusalem and Israeli settlements in the West Bank under the terms of international law.

On 3 May 2018, the OECD Council invited Lithuania to become a Member. At the time of preparation, the deposit of Lithuania's instrument of accession to the OECD Convention was pending and therefore Lithuania does not appear in the list of OECD Members and is not included in the OECD zone aggregates.

On 25 May 2018, the OECD Council invited Colombia to become a Member. At the time of preparation, the deposit of Colombia's instrument of accession to the OECD Convention was pending and therefore Colombia does not appear in the list of OECD Members and is not included in the OECD zone aggregates.

(C) OECD (2018)

You can copy, download or print OECD content for your own use, and you can include excerpts from OECD publications, databases and multimedia products in your own documents, presentations, blogs, websites and teaching materials, provided that suitable acknowledgment of OECD as source and copyright owner is given. All requests for commercial use and translation rights should be submitted to rights@oecd.org. 


\section{ABSTRACT/RÉSUMÉ \\ Enhancing dynamism in SMEs and entrepreneurship in Korea}

Making SMEs and start-ups a driver of growth and job creation requires a number of policies to improve the performance of SMEs, whose labour productivity in the manufacturing sector has fallen to less than a third of that in large companies. The large-scale support for SMEs should shift from supporting the survival of firms to raising productivity. Measures to accelerate SMEs' take-up of new technology and increase their participation in international trade would boost productivity and inclusive growth. Given the chronic labour shortages facing SMEs, reforming the education system to reduce labour market mismatch is a priority. Relaxing the regulatory burden and government control would allow innovative SMEs to create new products and services. Entrepreneurship is lagging, reflecting a higher fear of failure and a lack of skills in Korea. Upgrading entrepreneurship education and lowering the personal costs faced by entrepreneurs who fail would be beneficial. A greater role for venture capital, in part by activating the M\&A market to allow investors to recuperate their funds, would encourage firm creation.

This Working Paper relates to the 2018 OECD Economic Survey of Korea (www.oecd.org/eco/surveys/economic-survey-korea.htm)

JEL classification: L26, M13, O3

Keywords: Korea, small and medium-sized enterprises, SMEs, digitalisation, innovation, ecosystem, regulatory reform, public procurement, entrepreneurship, venture capital, start-ups, business angels, incubators, subcontractors, $R \& D$, productivity, insolvency regime.

\section{Accroître le dynamisme des PME et stimuler l'entrepreneuriat en Corée}

Faire des PME et des start-up un moteur de croissance et de création d'emplois nécessite un certain nombre de politiques pour améliorer les performances des PME, dont la productivité du travail dans le secteur manufacturier est inférieure à moins d'un tiers de celle des grandes entreprises. Le soutien à grande échelle aux PME devrait passer de ce soutien à la survie de celles-ci à l'accroissement de leur productivité. Des mesures visant à accélérer l'adoption des nouvelles technologies par les PME et à accroître leur participation au commerce international stimuleraient la productivité et la croissance inclusive. Compte tenu des pénuries chroniques de main-d'œuvre auxquelles sont confrontées les PME, la réforme du système éducatif pour réduire l'inadéquation du marché du travail est une priorité. L'assouplissement du fardeau réglementaire et du contrôle du gouvernement permettraient aux PME innovantes de créer de nouveaux produits et services. L'entrepreneuriat est à la traîne, reflétant une peur accrue de l'échec et un manque de compétences en Corée. La mise à niveau de la formation à l'entrepreneuriat et la réduction des coûts personnels encourus par les entrepreneurs en échec seraient bénéfiques. Un rôle accru du capital-risque, en partie en activant le marché des fusions et acquisitions pour permettre aux investisseurs de récupérer leurs fonds, encouragerait la création d'entreprises.

Ce Document de travail a trait à l'Étude économique de l'OCDE du Corée, 2018

(http://www.oecd.org/fr/eco/etudes/etude-economique-corée.htm).

Classification JEL : L26, M13, O3

Mots clés : Corée, petite et moyenne entreprises, PME, numérisation, innovation, écosystème, réforme réglementaire, marchés publics, entrepreneuriat, capital-risque, start-up, investisseurs providentiels, incubateurs, sous-traitants, R-D, productivité, régimes d’insolvabilité. 


\section{TABLE OF CONTENTS}

ENHANCING DYNAMISM IN SMES AND ENTREPRENEURSHIP IN KOREA .................................

Enhancing productivity of SMEs through innovation ........................................................................11

Weaknesses in digitalisation and automation slows innovation by SMEs .........................................13

Policies to promote digitalisation and the take-up of new technology .............................................15

Promoting SME innovation through R\&D and international links ...................................................17

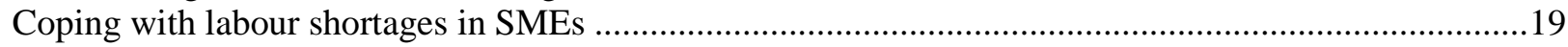

Reducing labour shortages in SMEs by addressing the mismatch in the labour market........................20

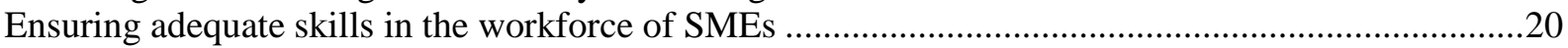

Enhancing SME productivity by strengthening linkages with global markets .......................................20

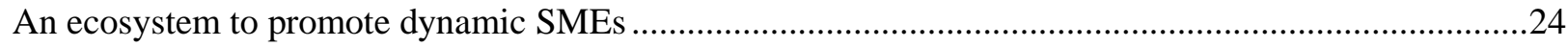

Regulatory reform to reduce the burden on SMEs and create new opportunities ..................................24

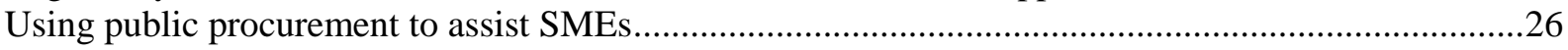

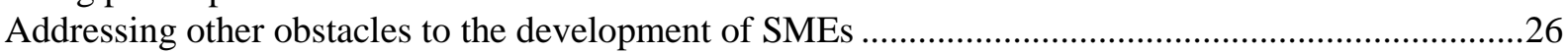

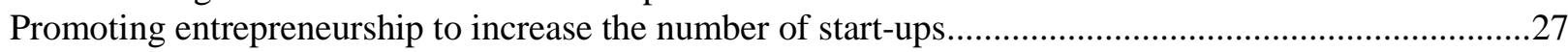

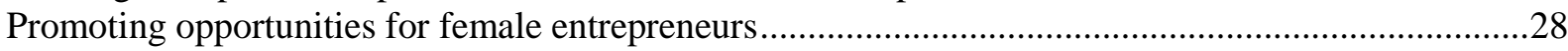

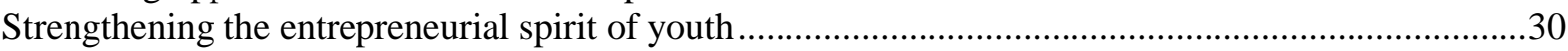

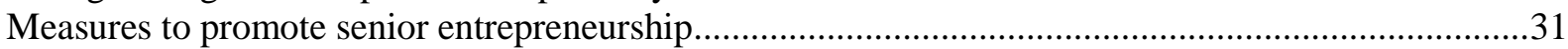

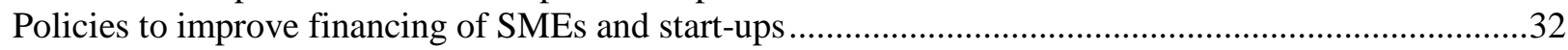

Venture capital to promote innovative start-ups ……............................................................................34

The Tech Incubator Programme for Start-ups (TIPS) ........................................................................

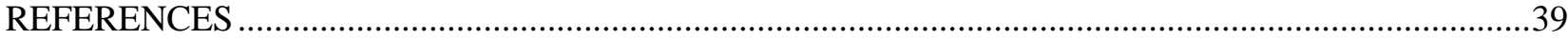

\section{Tables}

1. A comparison of large firms, mid-sized firms and SMEs...............................................................10

2. SMEs' share of manufacturing value added is edging up ............................................................11

3. SMEs, especially micro-firms, account for most of employment gains ...............................................11

4. SMEs are focused primarily on domestic markets...............................................................................21

5. There are a large number of economic regulations on SMEs ..............................................................25

6. Government support for female entrepreneurs is low .........................................................................30

7. The public sector's share of venture capital investment is falling but still high ....................................34

8. A comparison of Israel's TI programme with Korean incubator programmes .......................................38

\section{Figures}

1. Korea's output and export growth have slowed sharply ...................................................................

2. Labour income inequality is positively correlated with productivity disparities between firms .............7

3. Government credit guarantees for SMEs in Korea are exceptionally high............................................9

4. The share of employment in SMEs in Korea is the highest in the OECD ............................................

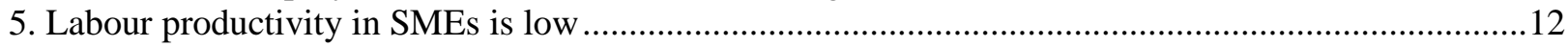

6. The ICT sector is large in Korea, and concentrated in manufacturing …..........................................13

7. The proportion of innovative firms among SMEs in Korea matches the OECD average .....................13

8. Korean firms lag significantly in their use of key digital technologies .................................................14 


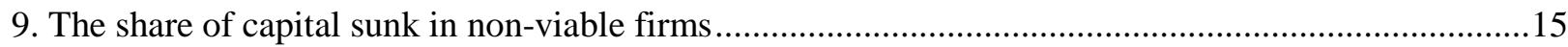

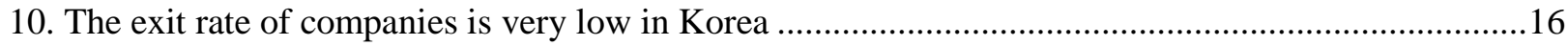

11. Korea ranks slightly below average in the OECD's indicator of insolvency regimes...........................17

12. $R \& D$ spending and government support for $R \& D$ are exceptionally high in Korea .........................17

13. Korean firms are less connected to global innovation networks.......................................................18

14. Korea's youth employment rate is below the OECD average and the number of NEETs is high.......19

15. The contribution of services to exports is relatively low in Korea ....................................................21

16. Korea should reduce barriers to trade in key services.........................................................................23

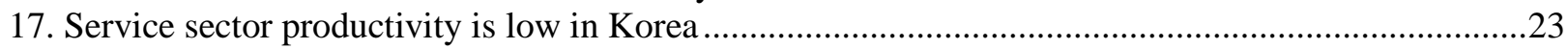

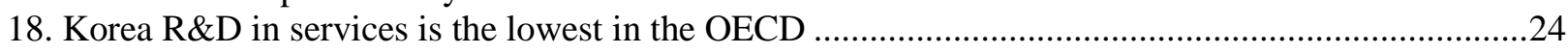

19. Korea is ranked $22^{\text {nd }}$ in the 2018 Global Entrepreneurship Index .................................................27

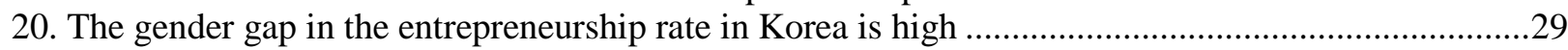

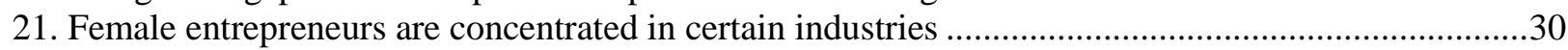

22. Korea's entrepreneurship rate for youth is far below the OECD average .........................................31

23. The interest rate spread between large firms and SMEs has fallen.....................................................32

24. Venture capital in Korea is among the highest in the OECD ..........................................................35

25. The recovery of investment funds through M\&As is still low in Korea..........................................36

26. Investment by angel investors has rebounded but remains below earlier peaks ...................................36

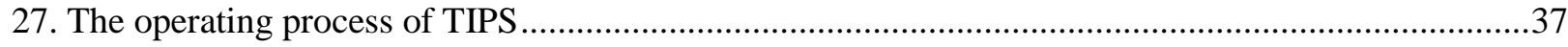

\section{Boxes}

Box 1. Initiatives launched by the new government to promote SMEs and start-ups ...............................8

Box 2. A statistical overview of large firms, mid-sized firms and SMEs in Korea....................................

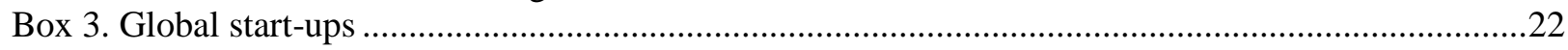

Box 4. A government plan to create an ecosystem to nurture innovative start-ups.................................28

Box 5. Korea's Tech Incubator Programme for Start-ups is based on Israel's programme.........................38

Box 6. Recommendations to enhance dynamism in SMEs and entrepreneurship ....................................39 


\title{
ENHANCING DYNAMISM IN SMES AND ENTREPRENEURSHIP IN KOREA
}

\author{
By Randall S. Jones and Jae Wan Lee ${ }^{1}$
}

In the new paradigm envisaged by the government, SMEs and start-ups will replace large firms as drivers of innovation. One reason for a new strategy is that the traditional model of growth led by exports of manufactures by large business groups, known as chaebols, which fuelled Korea's exceptionally rapid economic development, appears to be faltering (2018 OECD Economic Survey of Korea). Although economic growth typically slows as countries approach the high-income economies, the sharp deceleration from an annual rate of 6.4\% over 1991-2001 to 2.9\% since 2011 (Figure 1) raises concerns. Moreover, export volume growth slowed from a double-digit annual pace over 1991-2011 to 2.6\% since 2011, lagging behind global trade.

Figure 1. Korea's output and export growth have slowed sharply

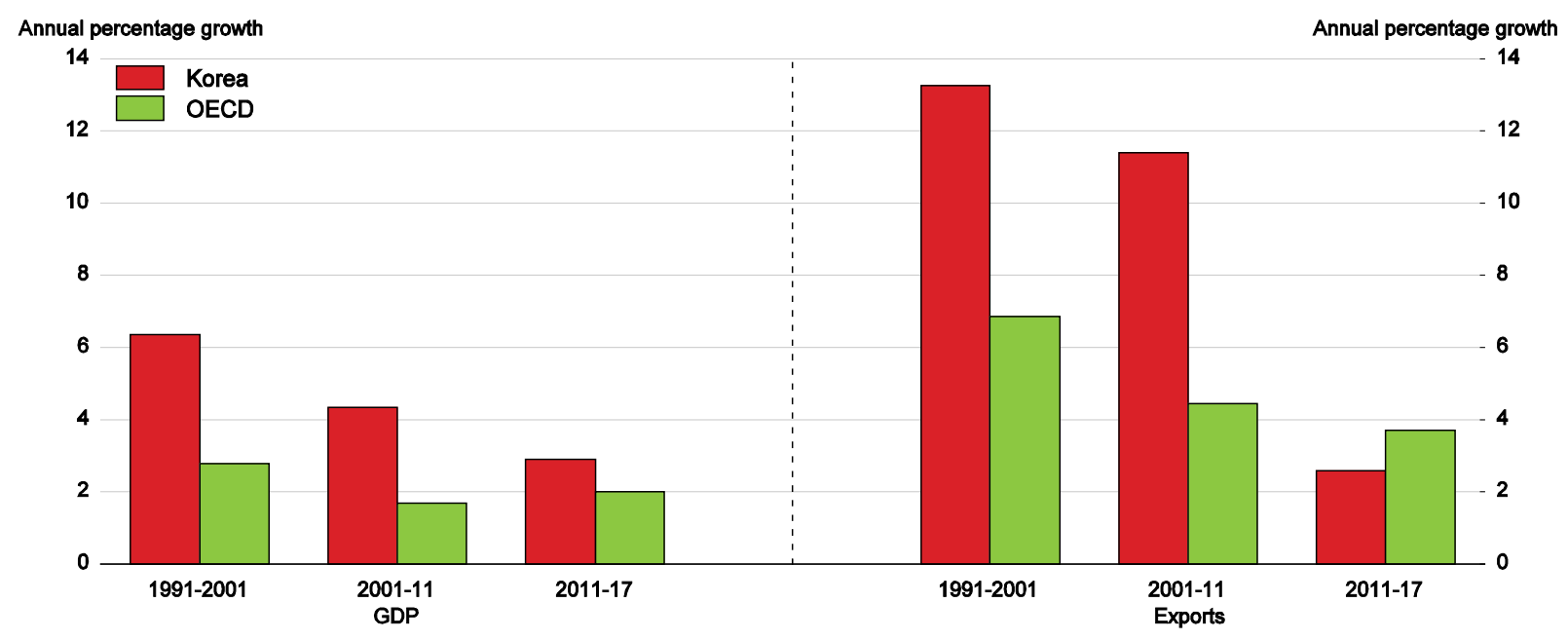

Source: OECD Economic Outlook: Statistics and Projections (database).

The export deceleration has limited the growth of employment and household income. In addition, the "trickle-down effect" - the expansion in domestic demand and employment for a given increase in exports - appears to be weakening. The additional value added and employment induced by production in the semiconductor, car, and ship industries has already started to decrease (Hong and Hong, 2017). In the face of intensified competition from emerging countries, particularly China, firms have limited wage increases and shifted production overseas. The share of overseas production by large firms rose from $16.8 \%$ in 2009 to $22.1 \%$ in 2014, with a negative effect on subcontracting companies. Large firms have also responded to intensified competition by increasing labour-saving investment and by shifting their product mix to more

1. Randall S. Jones is head of the Japan/Korea Desk in the Economics Department of the OECD and Jae Wan Lee was an economist on the Desk when the paper was written and now works in the Ministry of Economy and Finance in Korea. The authors would like to thank OECD Economics Department colleagues Robert Ford, Jens Hoj, Vincent Koen, Patrick Lenain, Alvaro Pereira, Sahra Sakha and Haruki Seitani, as well as Sebastian Schich and Martin Wermelinger (OECD Directorate for Financial and Enterprise Affairs), Mariarosa Lunati (Statistics and Data Directorate), Sarita Gomez and Sarah Perret (OECD Centre for Tax Policy and Administration), Victoria Galan Muros (OECD Directorate for Education and Training), Miriam Koreen (OECD Centre for Entrepreneurship, SMEs, Regions and Cities) and officials from the Korean government, for valuable comments and/or discussions. Special thanks go to OECD Economics Department colleagues Lutécia Daniel for technical assistance and Sisse Nielsen for technical preparation. 
capital and technology-intensive products. However, the experience of the past few years suggests that exports by large companies are not sufficient to sustain Korea's growth.

In addition, Korea's traditional growth model has led to economic polarisation and inequality. The economic dominance of large business groups, which received generous government support during the high-growth era (Jones, 2018), has stifled opportunities for small and medium-sized enterprises (SMEs). While the government has provided extensive support to SMEs, large productivity gaps between large firms and SMEs and between the manufacturing and service sectors have contributed to greater income inequality. Indeed, the dispersion between productivity in firms at the $90^{\text {th }}$ and $50^{\text {th }}$ percentiles in the OECD area is positively correlated with the dispersion in average wage income (Figure 2). For example, productivity and labour income gaps are relatively small in some northern European countries in contrast to some central European countries. The dispersion of productivity in Korea is the second highest in the OECD and the dispersion of wage income is the highest, boosted as well by labour market dualism.

Figure 2. Labour income inequality is positively correlated with productivity disparities between firms

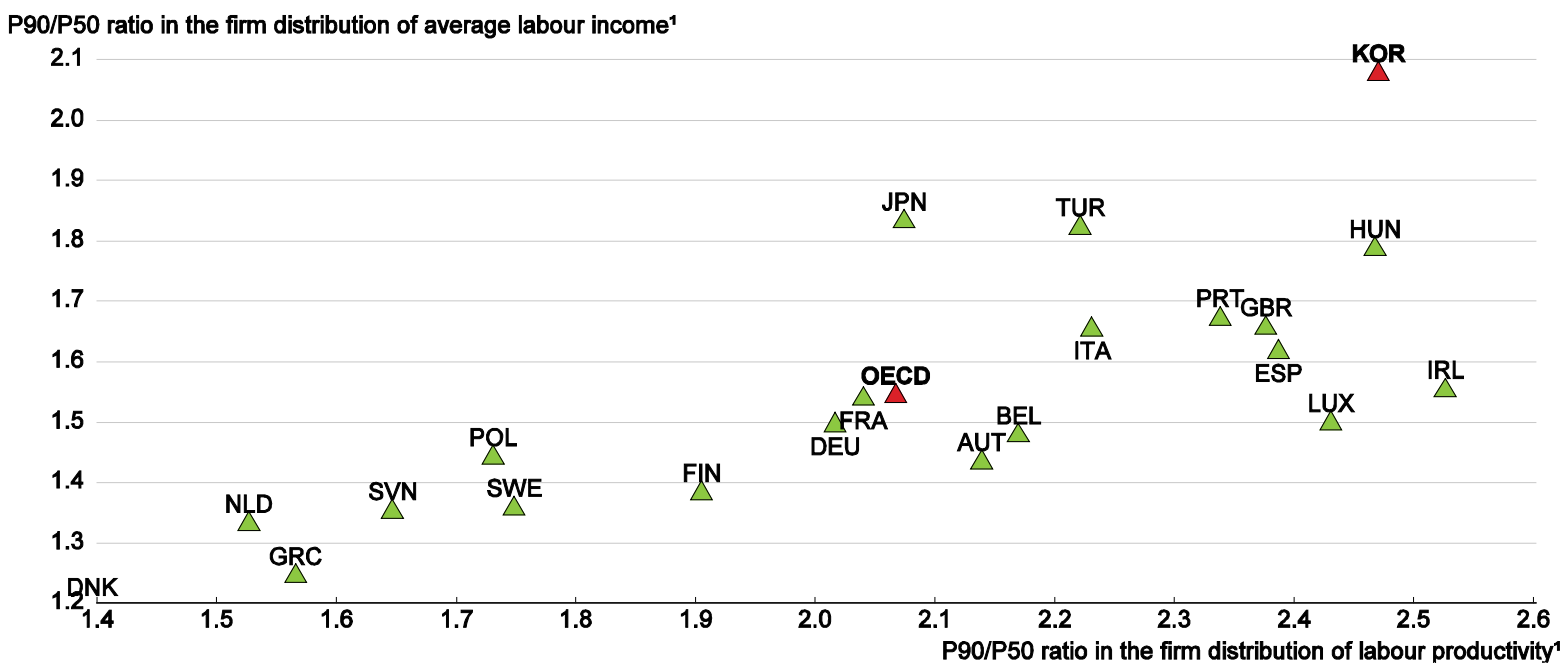

1. This figure compares the labour productivity and labour income of a firm at the $90^{\text {th }}$ percentile to one at the $50^{\text {th }}$ percentile. Source: OECD (2016c).

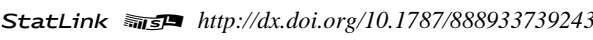

The lack of SME dynamism in an economy dominated by large manufacturing exporters is thus a source of inequality in addition to being a serious drag on output growth in Korea. Policies that improve the performance of SMEs will promote inclusive growth by creating job opportunities and boosting the quality of SME jobs by raising productivity and wages. Indeed, small enterprises are the main source of net job creation in the OECD (OECD, 2016b). In addition, development of SMEs tends to promote broad-based income gains across regions and industries, thereby reducing income inequality and poverty (OECD, 2009 and 2017c). Moreover, promoting innovative entrepreneurship is an important channel for enhancing social participation and mobility, particularly for women and youth.

Achieving inclusive growth thus requires policies that improve the performance of SMEs, particularly in the service sector. The longstanding government objective of promoting growth through innovation requires a greater contribution from SMEs. To accomplish this, the government aims to build an innovative ecosystem to foster SMEs, helping them to lead the fourth industrial revolution, and increase their participation in world trade. This emphasis is reflected in the creation of the Ministry of SMEs and Start-ups (MSS) in 2017. In addition, a range of new programmes is envisaged (Box 1). 


\section{Box 1. Initiatives launched by the new government to promote SMEs and start-ups}

\section{Measures to boost financing}

- The government is launching a KRW 10 trillion (USD 9.3 billion) venture capital investment fund.

- Increased financial support for SMEs is being provided through state-owned banks.

- The Ministry of SMEs and Start-ups (MSS) is boosting support for start-ups that contribute to job creation.

- The Financial Services Commission is working to attract more funds to SMEs and venture start-ups.

- $\quad$ The government is developing the KOSDAQ (Korean Securities Dealers Automated Quotations) market (a second-tier market for smaller firms) to support innovative SMEs.

- $\quad$ The central bank is increasing its lending support through financial intermediaries.

- $\quad$ The government is expanding assistance to SME exporters.

\section{Addressing labour shortages}

- $\quad$ The government is providing SMEs with annual support of KRW 20 million (USD 18 524) per newly hired young adult employee for three years.

- The government is encouraging young employees at SMEs to remain in their jobs by increasing the matching funds that it provides to their individual savings accounts.

\section{Other policies}

- $\quad$ To promote the fourth industrial revolution, MSS is introducing programmes, such as cross-generation startup teams, to promote the creation of new industries.

- MSS is implementing all of its start-up programmes as "Tech Incubator Programme for Start-ups", which provide mentoring and technology development.

- The government is protecting small merchants and SMEs by reducing costs, including labour, social insurance premiums, credit card fees, taxes, financial debts and rent.

- Penalties on unfair subcontracting practices are being increased and policies to eliminate such practices are to be introduced.

Building on the 2014 and 2016 OECD Economic Surveys of Korea, this paper analyses the current status of SMEs to develop policy directions that promote higher productivity and inclusive growth. After a brief overview of the SME sector, the second section discusses the need for innovation to increase productivity. The third section addresses an urgent need - overcoming the chronic labour shortages faced by SMEs. The benefits of increasing SMEs' role in international trade is analysed in the fourth section, followed by a discussion of various measures to improve the SME ecosystem. Policies to promote entrepreneurship are considered in the sixth section, followed by a discussion of SME financing issues. Specific policy recommendations are presented in Box 6 at the end of the paper.

\section{Overview of SMEs in Korea}

SMEs play a prominent role in Korea (Box 2). The early departure of employees from firms - before age 50 on average - prompts a large number to create small firms using their retirement allowance. SMEs are thus a key element of the social safety net. Korea's 1987 Constitution declares that the "State shall protect and foster SMEs". In 2017, there were 288 central government programmes to support SMEs, in addition to 1059 programmes at the local government level. Central government spending on such programmes amounted to $3.0 \%$ of its total spending in 2017. The government also provides large-scale support to SMEs through public funds and credit guarantees, which were the second largest in the OECD at 3.8\% of GDP in 2016 (Figure 3).

In addition, SMEs are assisted through: i) preferential treatment in public procurement; ii) lower tax rates at both the central and local government levels and preferential treatment that lower taxable income; 
iii) exemptions for associations of SMEs from the Monopoly Regulation and Fair Trade Act; iv) the right to hire foreign workers; and $v$ ) discounted prices for water and electricity. The decline in labour productivity in SMEs in manufacturing from more than half of large companies to less than a third (see below) calls into question the effectiveness of such support and the importance of new approaches.

Figure 3. Government credit guarantees for SMEs in Korea are exceptionally high

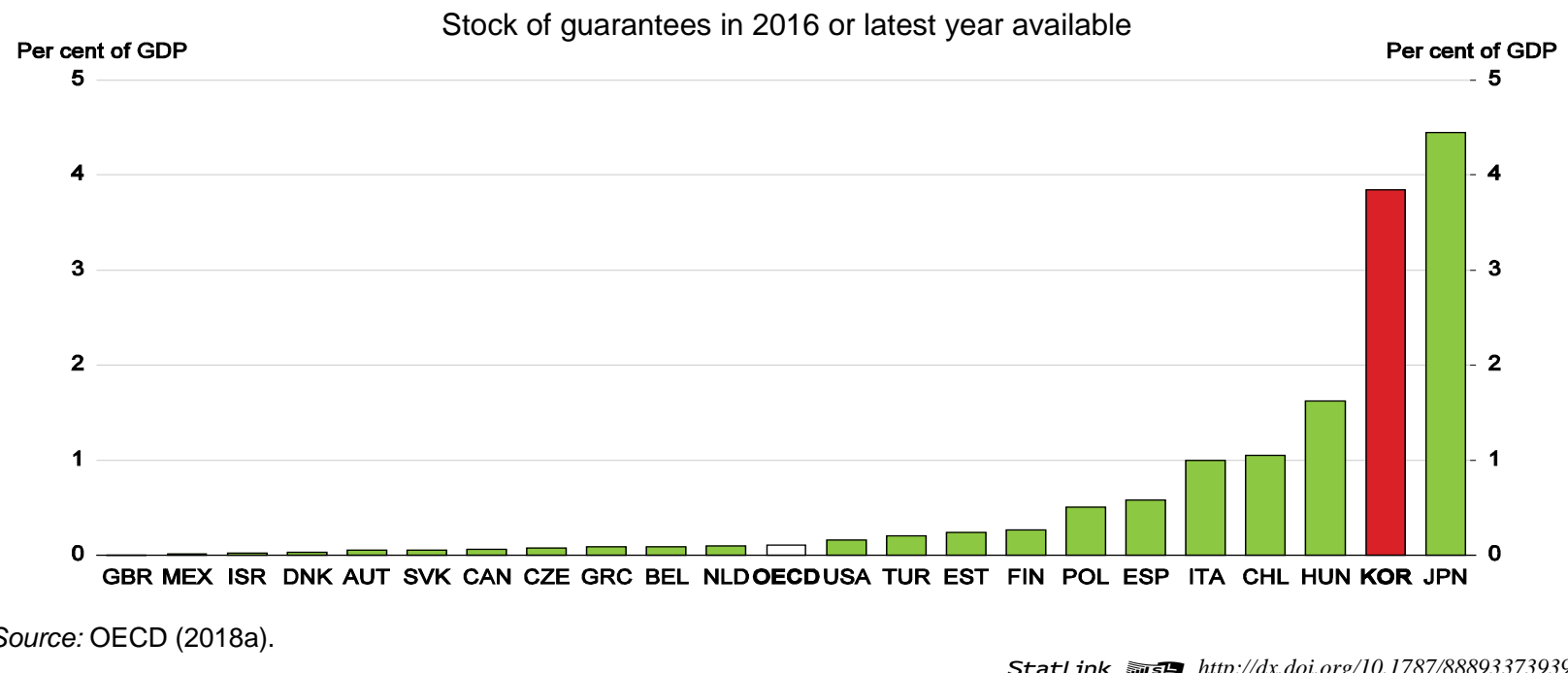

Box 2. A statistical overview of large firms, mid-sized firms and SMEs in Korea

There is no standard international definition of SMEs. For statistical purposes, the OECD defines SMEs as firms with up to 249 employees, divided into: micro-enterprises (1 to 9); small firms (10 to 49); and medium enterprises (50 to 249). By this definition, the share of workers employed at SMEs in Korea was the highest in the OECD at $88 \%$ in 2015 (Figure 4).

Figure 4. The share of employment in SMEs in Korea is the highest in the OECD

Percentage of all persons, total business economy, 2015 or latest available year

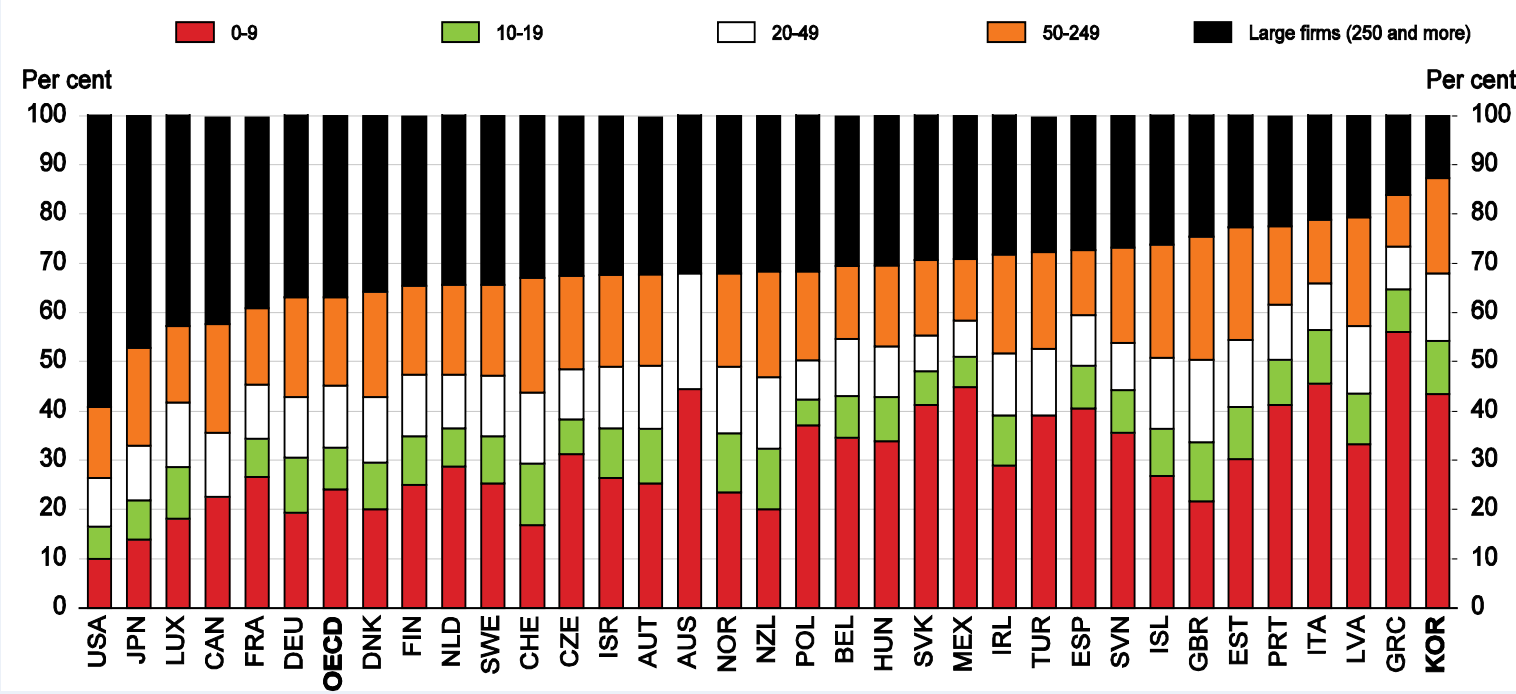

1. For Canada, Switzerland, Israel, Japan, Korea and the United States, data do not include non-employer enterprises, which are primarily self-employed persons. Data for Korea and Mexico are based on establishments. Data for the United Kingdom exclude an estimated 2.6 million small, unregistered businesses. For Australia, Canada and Turkey, the size class 1 9 refers to 1 19.

Source: OECD Structural and Demographic Business Statistics (ISIC Rev. 4) (database).

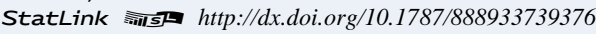


Until 2014, the definition of SMEs in Korea was based on the number of regular workers, sales, capital and total assets, with the thresholds varying by industry. However, this had a statistically significant negative impact on the growth of small firms: SMEs artificially stayed below the thresholds in order to continue receiving the favourable treatment offered to SMEs (Kim, 2017). To reduce this distortion, the definition was changed in 2015 to total assets (up to KRW 500 billion -- USD 463 million) and sales. To be classified as a SME, a firm's average sales during the past three years must not surpass a certain threshold of the industry in which they operate. The ceiling on sales ranges from KRW 40 billion (USD 37 million) to KRW 150 billion (USD 139 million) in the industries specified in the law on SMEs. However, the incentives for SMEs to remain below the threshold are still present under this revised definition.

Almost two-thirds of SME employment is in the service sector, with manufacturing accounting for another $27 \%$ and construction $8 \%$. SMEs accounted for $90 \%$ of employees in the service sector, $85 \%$ in construction and $81 \%$ in manufacturing in 2014 (OECD, 2017c).

In 2014, the government established an intermediate classification of mid-sized enterprises that includes firms that are too large to qualify as SMEs and are not affiliated with the large business groups that are subject to rules on cross-shareholding. Total assets of firms in this category must be between KRW 500 billion and KRW 10 trillion (USD 9.3 billion), which, as in the case of SMEs, creates disincentives to growth. This category excludes firms that are more than $30 \%$ owned by financial, public and non-profit institutions or whose largest shareholder is a foreign company. Although economic power is concentrated in the large enterprises (Jones, 2018), the mid-size firms, which are often referred to as "high potential enterprises", play an important and expanding role. Indeed, their growth in sales and assets in 2013 exceeded that of SMEs and large firms (Table 1).

SMEs accounted for $99.8 \%$ of firms and $76.8 \%$ of employment in 2014 (Table 1). In addition, SMEs had the largest proportion of sales, although large enterprises accounted for two-thirds of exports. However, SMEs had the lowest operating profit margin and the highest debt-to-equity ratio (Panel C), although this partly reflects the fact that they tend to be younger than larger firms.

Korea faces large and widening gaps in labour productivity between the different firm sizes. Indeed, the labour productivity of SMEs is only about half of mid-sized firms, which in turn is a bit more than half of the large firms. As noted above, large productivity gaps exacerbate income inequality and are an obstacle to inclusive growth. In addition, the low productivity in SMEs and mid-sized firms handicaps large firms, whose international competitiveness depends in part on the efficiency of its suppliers. Low productivity in smaller firms thus tends to accelerate off-shoring.

Table 1. A comparison of large firms, mid-sized firms and SMEs

\begin{tabular}{|c|c|c|c|}
\hline \multicolumn{4}{|c|}{ A. Percentage of total in 2014} \\
\hline & Large enterprises & Mid-size firms $^{1}$ & SMEs \\
\hline Enterprises & 0.05 & 0.12 & 99.8 \\
\hline Employees & 13.5 & 9.7 & 76.8 \\
\hline Sales & 40.2 & 14.8 & 45.0 \\
\hline Exports & 67.0 & 15.7 & 17.1 \\
\hline \multicolumn{4}{|c|}{ B. Percentage growth in 2013} \\
\hline Sales & 0.3 & 5.8 & 5.6 \\
\hline Assets & 7.9 & 8.3 & 3.6 \\
\hline \multicolumn{4}{|c|}{ C. Ratios in 2013} \\
\hline Operating profits margins ${ }^{2}$ & 4.7 & 4.1 & 3.2 \\
\hline Debt-equity ratio & 133.5 & 120.2 & 168.3 \\
\hline Labour productivity $^{3}$ & 100.0 & 56.2 & 28.8 \\
\hline
\end{tabular}

1. Often referred to as high potential enterprises.

2. As a percentage of sales.

3. Labour productivity as per cent of that in large companies.

Source: Statistics Korea.

SMEs' share of value added in manufacturing edged up from 47.4\% in 2004 to $49.1 \%$ in 2014 (Table 2). While their share in heavy industry also increased slightly, it remains much less than the SMEs' $84.6 \%$ share of value added in light industry. The concentration of SMEs in labour-intensive sectors is a key reason for their lower wages and productivity. It also makes SMEs the main source of job creation. Firms with less than 300 employees accounted for 91.9\% of the employment gains in 2015 (Table 3). Micro-firms (those with less than ten employees) alone accounted for three-quarters. 
Table 2. SMEs' share of manufacturing value added is edging up

\begin{tabular}{|c|c|c|c|c|c|c|c|}
\hline \multicolumn{8}{|c|}{ Percentage of value added } \\
\hline \multicolumn{4}{|c|}{2004} & \multicolumn{4}{|c|}{2014} \\
\hline & Light $^{1}$ & Heavy $^{2}$ & Total & & Light $^{1}$ & Heavy $^{2}$ & Total \\
\hline SMEs & 77.9 & 39.4 & 47.4 & SMES & 84.6 & 41.3 & 49.1 \\
\hline Large firms & 22.1 & 60.6 & 52.6 & Large firms & 15.4 & 58.7 & 50.9 \\
\hline Total & 100.0 & 100.0 & 100.0 & Total & 100.0 & 100.0 & 100.0 \\
\hline
\end{tabular}

1. Light industry includes food and beverages, tobacco, textiles, clothing, leather products, wood and wood products, paper and paper products, printed and recorded products, rubber and plastic products, furniture and other products.

2. Heavy industry includes refined petroleum products; chemicals and chemical products; medical materials and medicines; nonmetal mineral products; primary metals; metal processing products; electronic components; communication, computer, video and audio equipment; medical, precision and optical machinery; watches; electrical equipment; other machinery; cars; and other transport equipment.

Source: Statistics Korea, Survey of Mining and Manufacturing.

Despite increasing government support, the growth of value added per worker in SMEs has been on a downward trend (Figure 5). Labour productivity in SMEs in manufacturing fell from 53.8\% of that in large firms in 1988 to 32.5\% in 2014 (Panel B). The productivity gap between large firms and SMEs is one of the biggest in the OECD (Panel C). While data are not available for the entire service sector, labour productivity of small firms (one to nine employees) in the retail and wholesale sector was only $24 \%$ of that in large firms in 2012, the largest gap among the 25 countries for which data are available (OECD, 2015b). Low productivity in SMEs may be related in part to weak investment, which has limited their role in the transition to technology and knowledge-intensive activities. On the positive side, their financial structure has been strengthened: the debt-to-equity ratio of SMEs, which soared to $305.5 \%$ during the financial crisis in 1997 , fell to $168 \%$ in 2013.

Table 3. SMEs, especially micro-firms, account for most of employment gains

Thousand workers in 2015

\begin{tabular}{|c|c|c|c|c|}
\hline \multirow{2}{*}{$\begin{array}{l}\text { Firms by } \\
\text { number of } \\
\text { employees }\end{array}$} & \multicolumn{2}{|c|}{ Gain in employment due to: } & \multirow{2}{*}{$\begin{array}{c}\text { Net gain in } \\
\text { employment } \\
A+B\end{array}$} & \multirow{2}{*}{$\begin{array}{c}\text { Share of employment } \\
\text { gains (\%) }\end{array}$} \\
\hline & $\begin{array}{l}\text { Establishment and closure of } \\
\text { firms }(A)\end{array}$ & $\begin{array}{l}\text { Growth and decline of } \\
\text { firms (B) }\end{array}$ & & \\
\hline $0-4$ & 125 & 129 & 254 & 64.1 \\
\hline $5-9$ & 47 & 1 & 48 & 12.1 \\
\hline $10-29$ & 42 & -6 & 36 & 9.1 \\
\hline $30-99$ & 27 & -11 & 16 & 4.0 \\
\hline $100-299$ & 15 & -5 & 10 & 2.5 \\
\hline Under 300 & 256 & 108 & 364 & 91.9 \\
\hline $300+$ & 9 & 23 & 32 & 8.1 \\
\hline Total & 265 & 131 & 396 & 100.0 \\
\hline
\end{tabular}

Source: Noh (2017).

\section{Enhancing productivity of SMEs through innovation}

In the new paradigm envisaged by the government, Korea will shift from a fast follower adopting technology developed elsewhere to a first mover, led by SMEs and start-ups. SMEs and start-ups play a central role in innovation in many countries. As they tend to operate outside the dominant paradigm, they can more freely explore technology and commercial opportunities that tend to be overlooked by existing firms (Baumol, 2002; OECD, 2010). The advent of digitalisation is changing the business environment by levelling the playing field between SMEs and larger firms. A small firm today has access to communications and information systems that were available only to large multinationals a few decades ago. The active use 
of digital platforms can improve the productivity and price competitiveness of SMEs compared to large enterprises. It can also enhance access to alternative financial instruments and promote the emergence of innovative start-ups by using the Internet to lower fixed costs and outsource important functions (OECD, 2017b). Even micro businesses can engage in exports as a major activity, capitalising on digital tools. Twothirds of SMEs that export report that more than half of their international sales depend on online tools (OECD, 2017c).

Figure 5. Labour productivity in SMEs in manufacturing is low

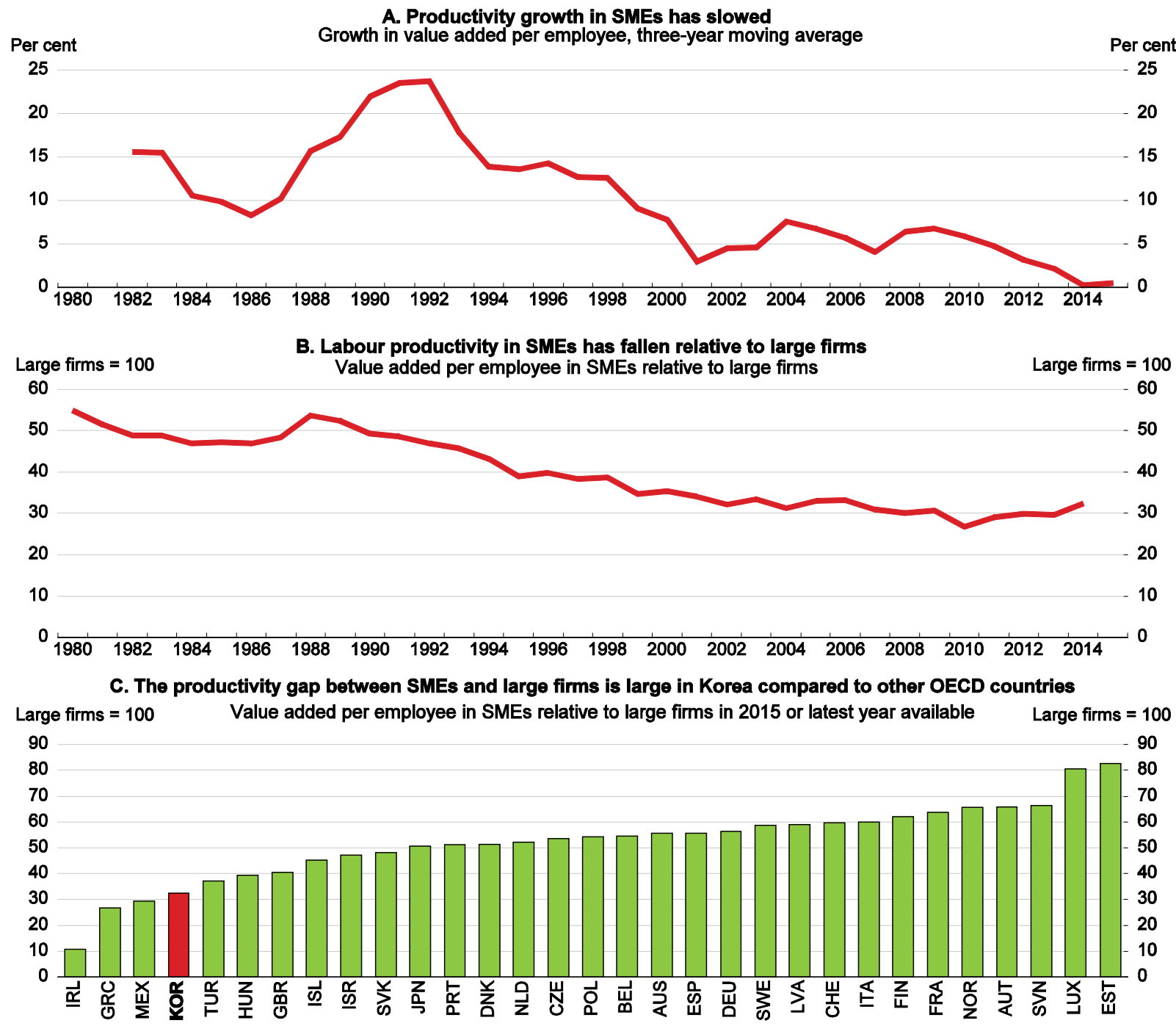

Source: Statistics Korea, KOSIS database; OECD Structural and Demographic Business Statistics (ISIC Rev. 4) (database).

Building on its position as a world-leader in the provision of Information and Communications Technology (ICT) goods and benefiting from extensive broadband deployment, Korea has great scope to harness the potential of the digital economy to drive productivity. Korea's large and growing ICT sector accounted for over $10 \%$ of value added in 2015, double the OECD average (Figure 6). However, this reflects the large share of ICT manufacturing (7\% of value added). In contrast, telecommunications, IT and other information services were below the OECD average as a share of GDP. 
Figure 6. The ICT sector is large in Korea, and concentrated in manufacturing

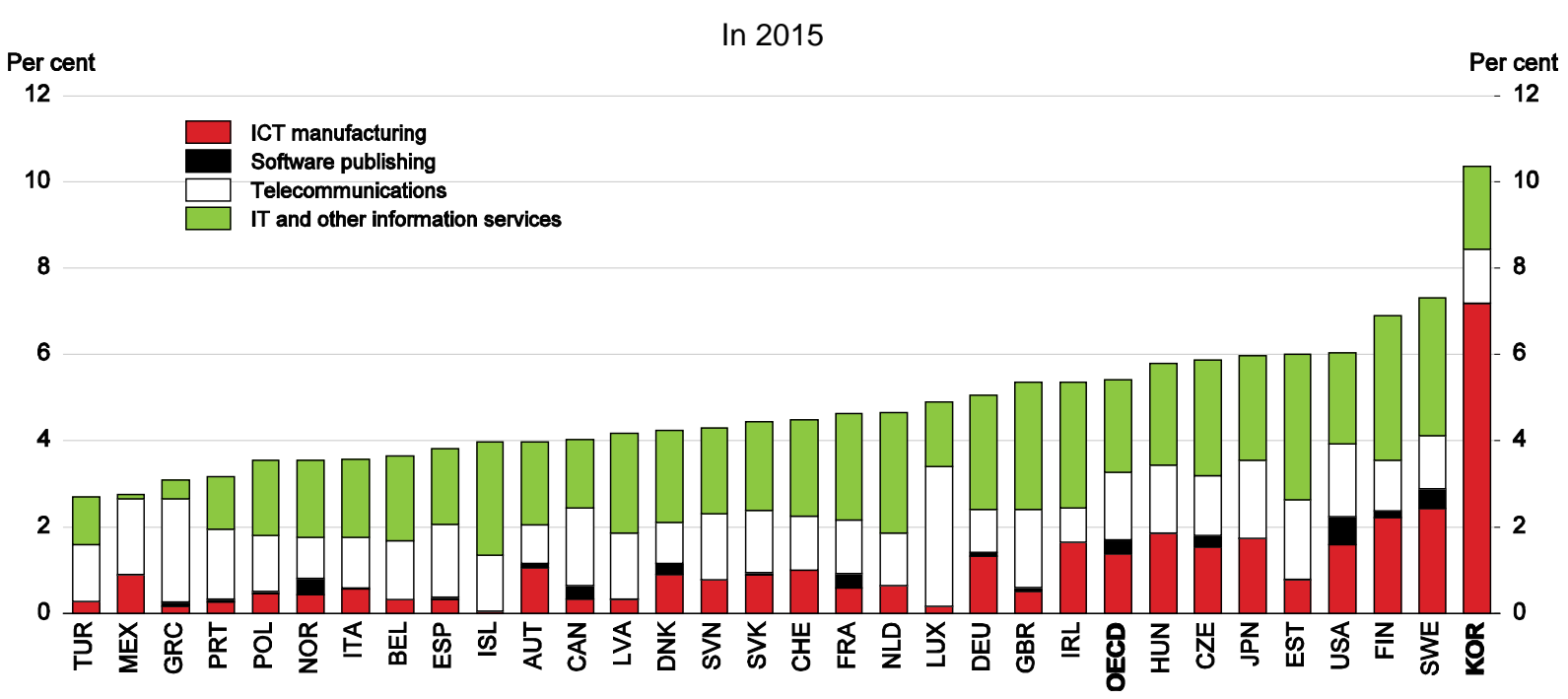

Source: OECD (2017e), OECD Digital Economy Outlook 2017.

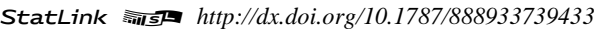

\section{Weaknesses in digitalisation and automation slows innovation by SMEs}

The proportion of innovative firms among SMEs is around the OECD average, but there is considerable scope for improvement to match the best performers (Figure 7). To generate innovation and new markets, it is essential to develop "convergence technology" -- notably sensors, robots, and 3D printing -- which integrates the possibilities generated by ICT. However, only 2.5\% of Korean SMEs have acquired these technologies.

Figure 7. The proportion of innovative firms among SMEs in Korea matches the OECD average

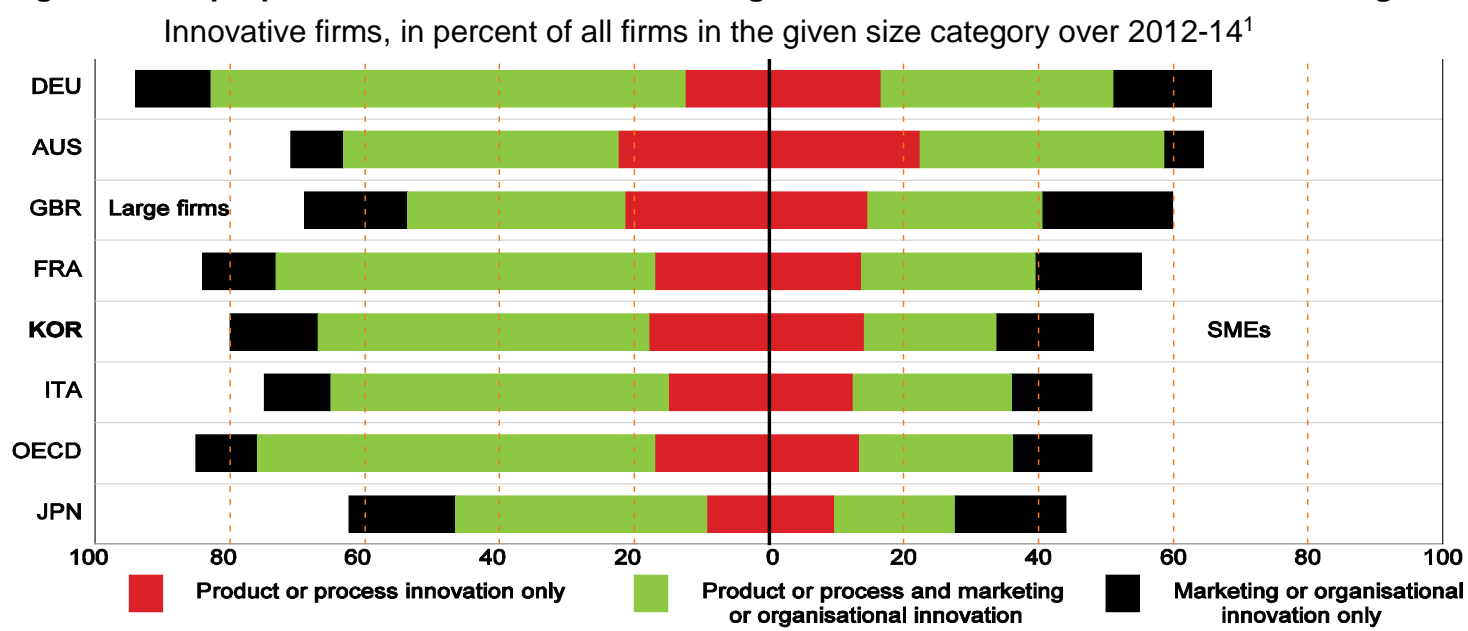

1. For Korea, 2013-15.

Source: OECD (2017f), OECD Science, Technology and Industry Scoreboard 2017.

StatLink 尚Is http://dx.doi.org/10.1787/888933739452

In particular, Korean firms lag far behind in their use of cloud computing technology, a key ICT convergence technology (Figure 8). The share of firms in Korea with between 50 and 249 employees that used cloud computing in 2016 was 10\%, one-third of the OECD average. Cloud computing allows SMEs to overcome the barrier of high fixed costs associated with the use of "big data", which is generated from 
activities that are carried out electronically and from machine-to-machine communications. Big data is a useful tool given its vast volume, variety and the velocity at which data are generated. For example, it allows SMEs to improve their production processes, satisfy the needs of customers, and gain a better understanding of the business environment. The share of Korean SMEs using big data was only 4\% in 2016, well below the $11 \%$ OECD average (Panel B), reflecting their limited use of cloud computing.

Figure 8. Korean firms lag significantly in their use of key digital technologies

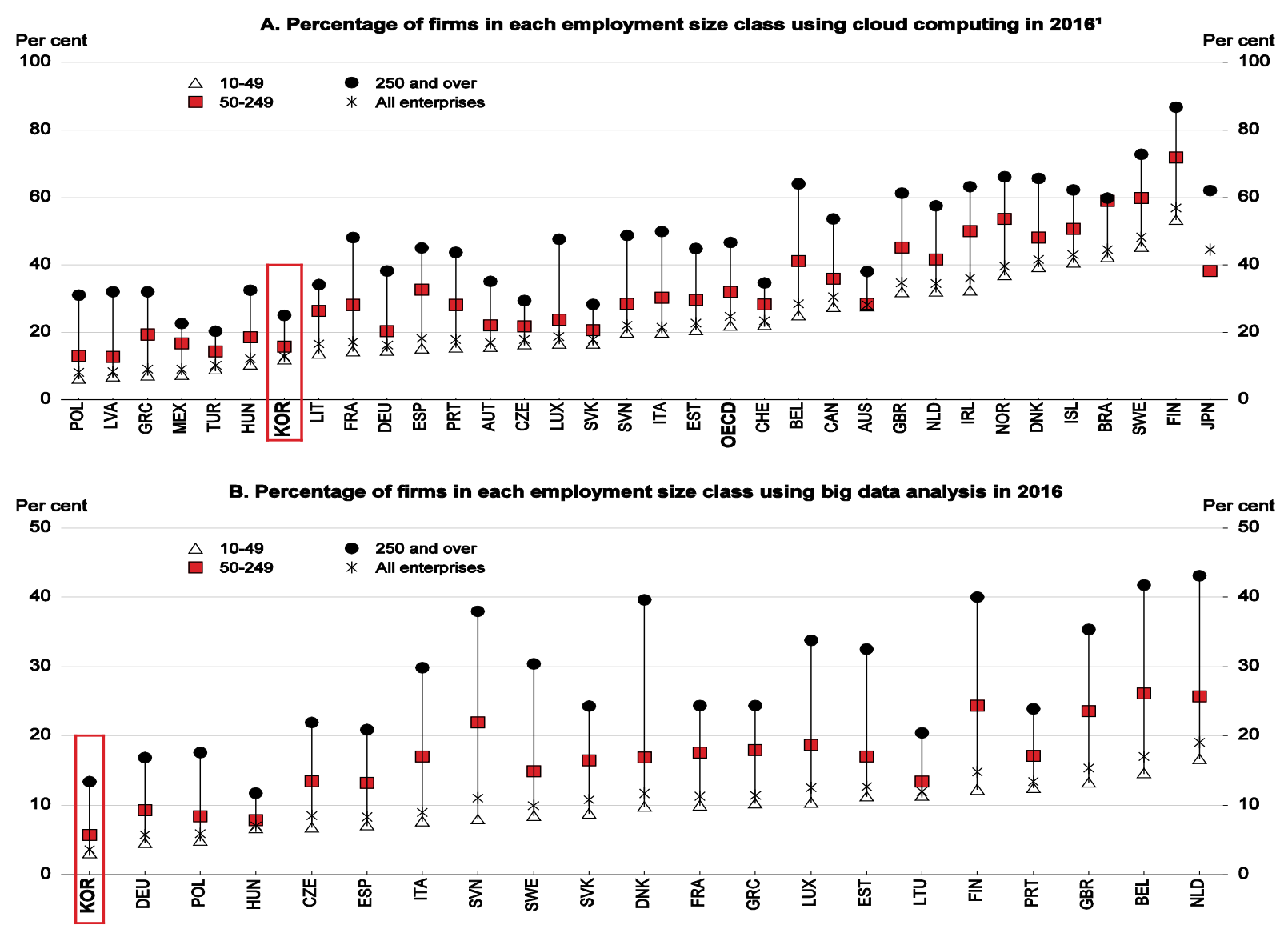

1. Cloud computing refers to ICT services used over the Internet as a set of computing resources to access software, computing power, storage capacity and so on. Data refer to manufacturing and non-financial market services enterprises with ten or more persons employed, unless otherwise stated. Size classes are defined as: small (10 49 persons employed), medium (50 249) and large (250 and more). The OECD average in Panel $A$ is a simple average of the available countries.

Source: OECD (2017e), OECD Digital Economy Outlook 2017.

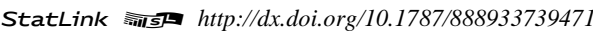

In addition, 62.5\% of SME exporters have not automated their manufacturing processes (Chang and Lee, 2017). Moreover, the level of automation that has been introduced is relatively basic, consisting of barcodes $(17 \%)$ or radio-frequency identification $(14 \%)$. The reason that SMEs do not automate their manufacturing processes is that more than half of them do not feel the necessity of automation. This suggests a lack of competition that would oblige firms to introduce automation to ensure their survival.

The creation of smart factories, based mainly on ICT, occurs primarily among large firms, while the share of SME workplaces converted to smart factories is low at $7.4 \%$. To assist SMEs, the government announced that it would help 20000 SMEs establish smart factories, which integrate software and the Internet of Things (IOT), by 2022. Half of the KRW 2 trillion (USD 1.85 billion) in funding is from the government with the other provided by the firms. In addition, the Korea Smart Factory Foundation supports SMEs that have limited technological capability. In order to accelerate the spread of smart factories, it is 
necessary to address the problems of redundant investment due to delayed standardisation, the leakage of internal technology to large firms and rising fixed costs. In addition, the diffusion of smart factories is limited by reliance on expensive foreign solutions (K. Chang, 2017). A lack of human resources in digitalisation also slows the introduction of technology in SMEs, which do not have the financial strength to match salaries offered by large firms (see below).

\section{Policies to promote digitalisation and the take-up of new technology}

The gap between firms at the technological frontier and lagging firms in the global economy has widened in recent years. This reflects, in part, the increasing cost and technical sophistication of new investments necessary to introduce cutting-edge technology. In addition, "it has become relatively easier for weak firms that do not adopt the latest technology to remain in the market” (Andrews et al., 2016). The survival of non-viable firms traps workers and capital in unproductive activities. In Korea, more than $10 \%$ of the capital stock in 2013 was sunk in non-viable ("zombie”) firms, defined as more than ten years old with an interest coverage ratio of less than one for more than three consecutive years (Figure 9).

Figure 9. The share of capital sunk in non-viable firms

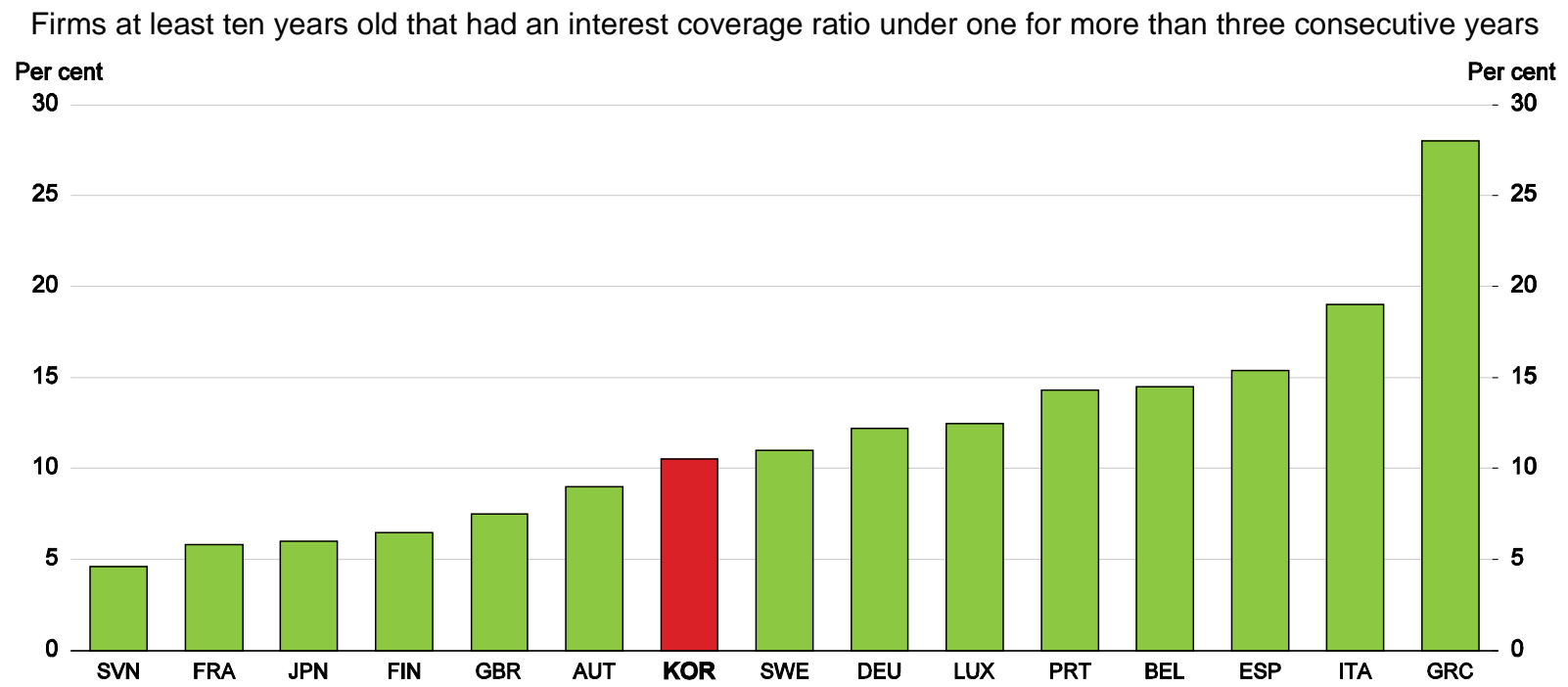

Source: Adalet McGowan et al. (2017a).

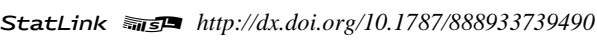

Policies to spur competition are needed to encourage reallocation and increase firms' incentives to increase digitalisation and other key technologies. The most effective policies in this regard include (Andrews et al., 2018):

- $\quad$ Reduce barriers to international trade and inward foreign direct investment.

- Employment flexibility, which facilitates the expansion of innovative firms and the downsizing of lagging firms. However, Korea was ranked $106^{\text {th }}$ in the world in labour market flexibility and $112^{\text {th }}$ in the cost of redundancy by the Global Competitive Index (World Economic Forum, 2017).

- Insolvency regimes that promote productivity by strengthening market selection and the reallocation of resources to more productive uses (see below).

- Venture capital investment, which promotes the creation of innovative firms. Korea ranks fourth highest in the OECD with respect to venture capital investment as a share of GDP (see below). 
- Avoiding high corporate income tax rates promotes firm creation. Korea's corporate tax rate was $22 \%$ in 2016, slightly below the $24.6 \%$ OECD average, but was raised to $25 \%$ for 77 large firms in 2017.

Firm entry and exit drive the "creative destruction" that leads to technological change and productivity growth. However, the firm exit rate has been falling in Korea and was the third lowest in the OECD area in 2014 (Figure 10), reflecting in part weakness in the insolvency regime (Adalet McGowan et al., 2017b). The problems of weak market selection, survival of non-viable firms and inefficient capital reallocation are likely to be more pronounced in economies where insolvency regimes: i) impose a high personal cost on failed entrepreneurs; ii) lack sufficient preventive measures; and iii) lack tools to facilitate restructuring. In the OECD's indicator of insolvency regimes, Korea ranked below average (Figure 11), reflecting problems in three areas:

- The time to discharge -- the number of years a bankrupt person must wait until they are discharged from pre-bankruptcy indebtedness - is long in Korea, raising the personal costs associated with entrepreneurial failure.

- Korea lacks an early warning system for bankruptcy, although the government has provided business consulting services since 2013.

- Korea has an indefinite stay on assets, which stops actions by creditors to collect debts from a debtor.

Figure 10. The exit rate of companies is very low in Korea

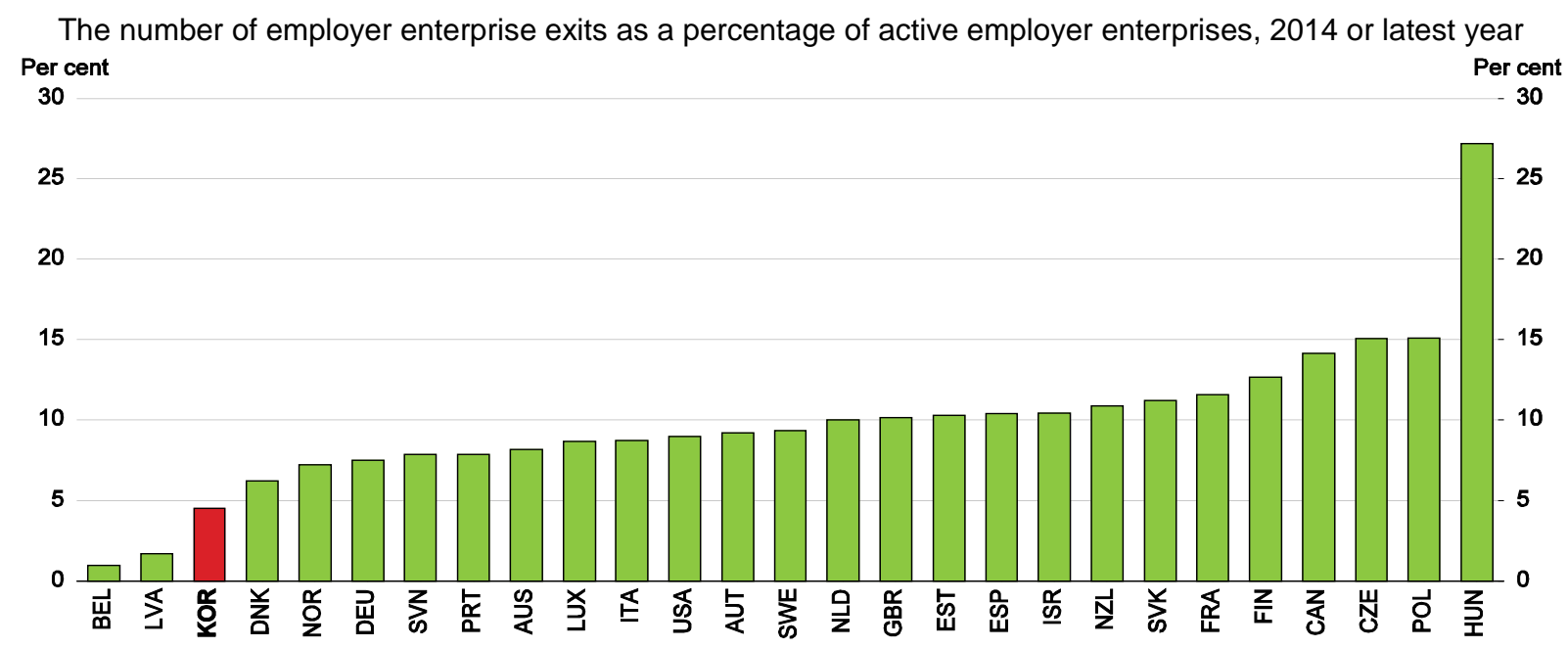

Source: OECD (2017c), Entrepreneurship at a Glance 2017. 
Figure 11. Korea ranks slightly below average in the OECD's indicator of insolvency regimes

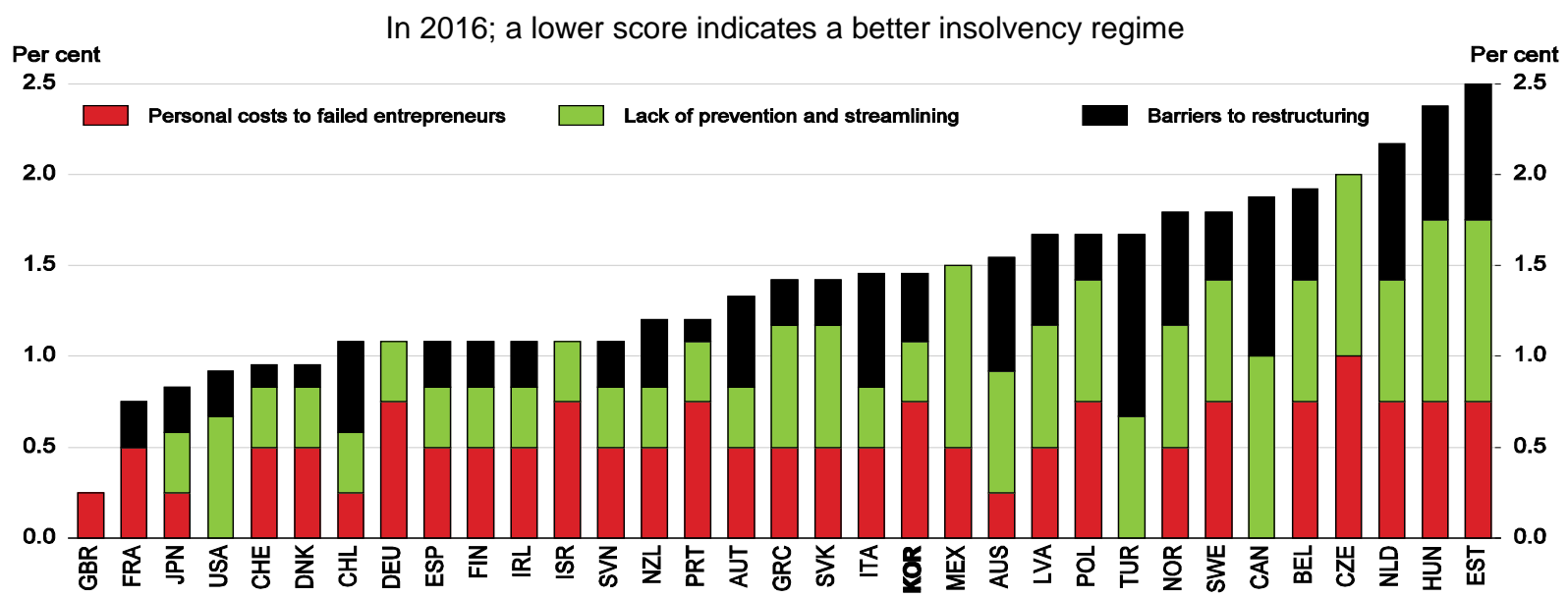

Source: Adalet McGowan et al. (2017b).

\section{Promoting SME innovation through R\&D and international links}

Korea's total R\&D spending has risen rapidly since 2000, reaching 4.2\% of GDP in 2015, the second highest in the OECD (Figure 12). Business expenditure on R\&D is the highest in the OECD at 3.2\% of GDP, underpinned by government support equivalent to $0.35 \%$ of GDP, the fourth highest in the OECD (Panel B). To promote innovation, the government provides tax incentives for R\&D, asset acquisition, technology commercialisation and human resource support.

Figure 12. R\&D spending and government support for R\&D are exceptionally high in Korea

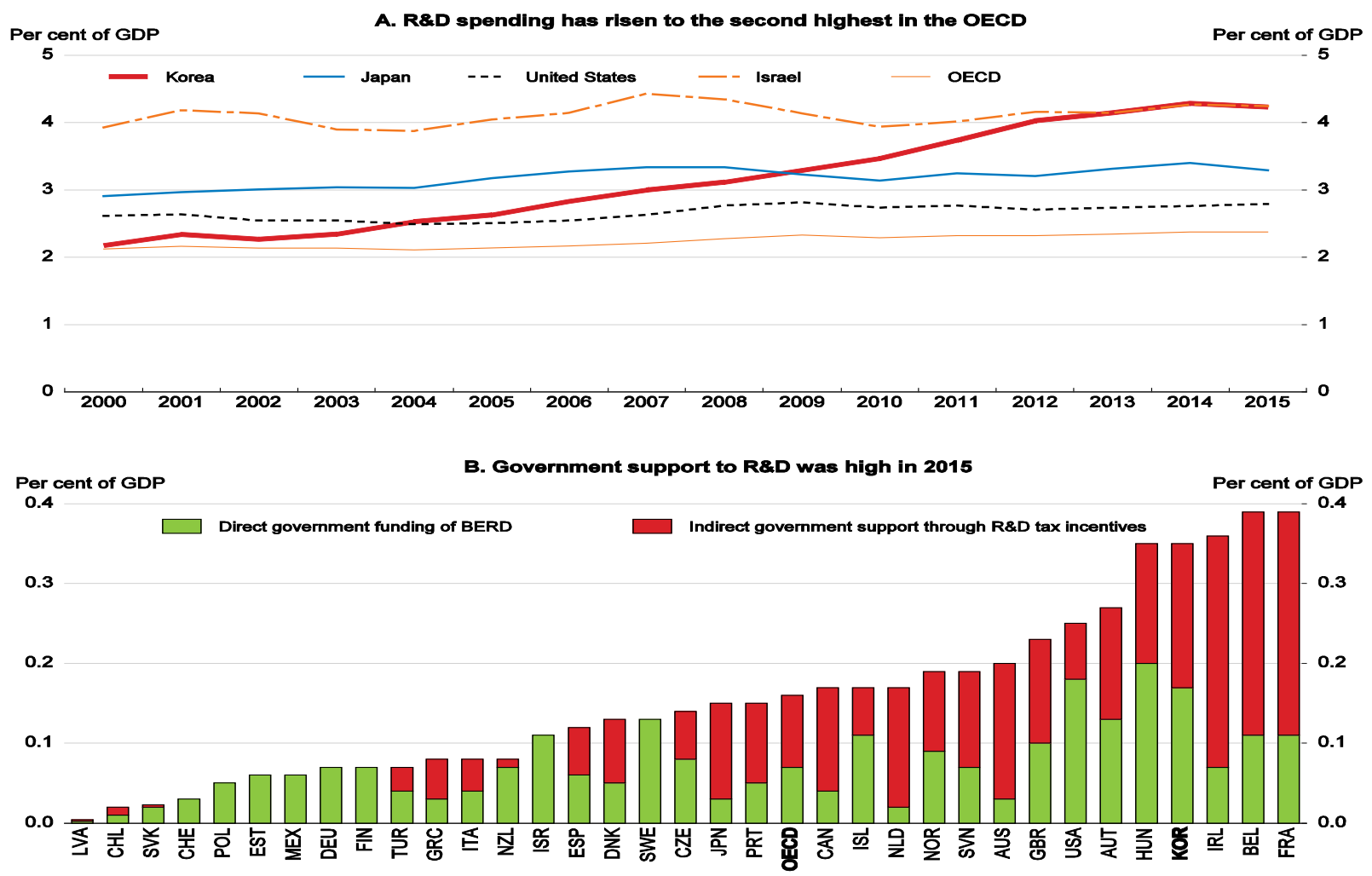


However, the traditional chaebol-led R\&D model, focusing on manufacturing, cannot achieve the government's goal of achieving a fourth industrial revolution. SMEs' low level of investment in R\&D and other knowledge-based assets has slowed their uptake of new technology, including digitalisation. SMEs account for about 20\% of business R\&D, compared to an OECD average of around 30\% (OECD, 2016e). The lower R\&D investment by SMEs reflects in part their concentration in services (see below). At present, SMEs can choose between a tax credit of $25 \%$ of spending on research and manpower development expenses or $50 \%$ of the additional spending above the average of the past year. Marginal R\&D tax subsidy rates (the generosity of the tax system for a marginal unit of R\&D expenditure) for Korean SMEs are relatively high at 0.25 for profit-making firms (versus an OECD median of 0.18) and 0.20 for loss-making firms (OECD median of 0.11 ). In contrast, the R\&D tax subsidy rates for large firms are 0.04 for profit-making ones and 0.03 for loss-making ones (OECD, 2017i).

Given SMEs generally low productivity and weak financial position, it is important to ensure that R\&D incentives are effective for them. The tax incentive for SMEs could be strengthened by combining a basic deduction for R\&D spending, with a deduction for a certain amount of additional spending. Start-ups are typically not profitable in their early years so the R\&D tax credit, which applies to the corporate income tax, does not provide any incentive to invest. Although unused credits can generally be carried forward for five years (OECD, 2017i), many start-ups do not survive that long. Allowing the R\&D tax credit to be used immediately to offset other business taxes would encourage greater R\&D (Noh, 2017).

Open or network-based innovative knowledge economies can help new and small businesses participate in innovation (OECD, 2010). Digitalisation facilitates collaborative networks with multinational corporations, universities and research institutes around the world by reducing costs (OECD, 2015b). However, in Korea, both large firms and SMEs rank last in the OECD measure of international innovation co-operation (Figure 13). Moreover, Korea ranked third lowest in 2015 in its share of R\&D funding from overseas. Korea also ranked second lowest in international co-patenting and third lowest in international science co-operation in 2013. The government has developed a plan to promote such co-operation, emphasising the creation of a global network of overseas science, technology and innovation outposts, expansion of S\&T official development assistance, promotion of international joint R\&D, and sharing of large R\&D facilities. These measures could be usefully complemented by reducing barriers to trade and investment, which would facilitate foreign investment in R\&D and help Korea connect to global science and innovation networks (2016 OECD Economic Survey of Korea).

Figure 13. Korean firms are less connected to global innovation networks

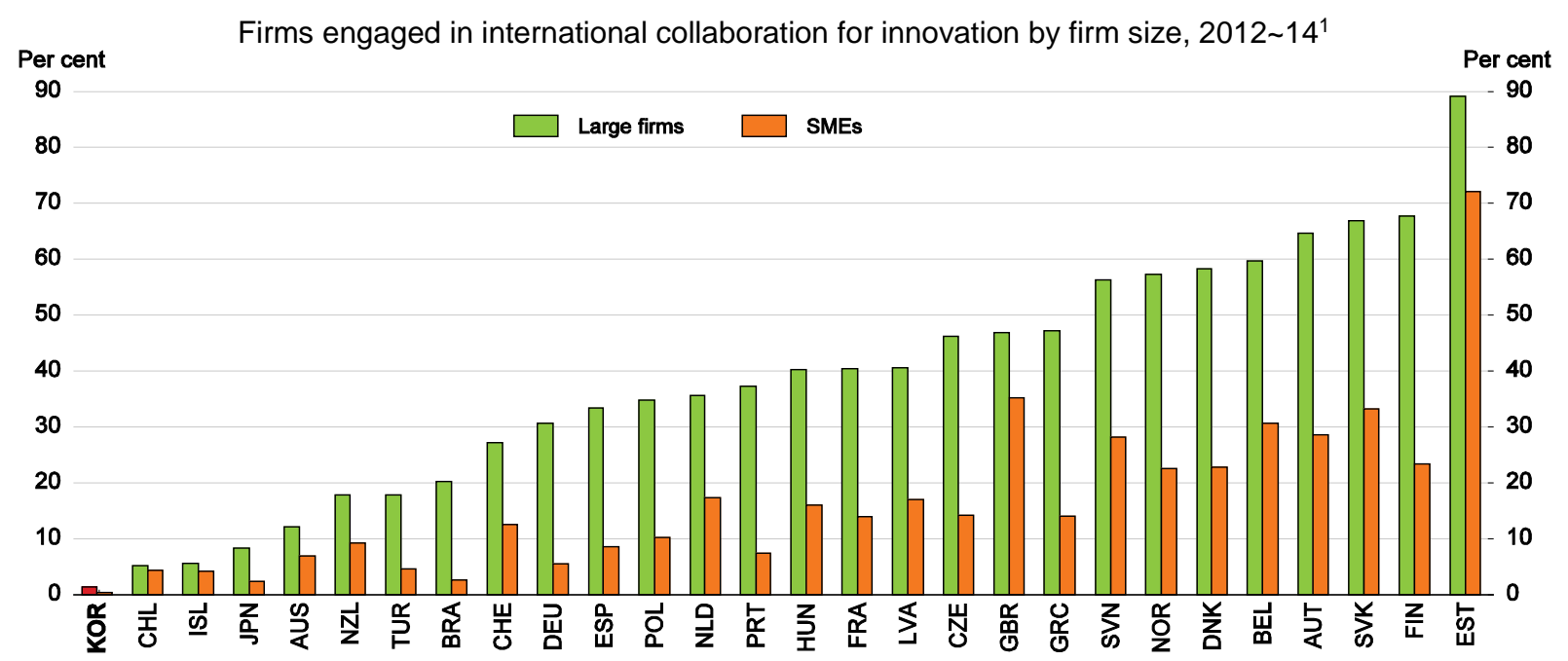

1. As a percentage of firms engaged in product or process-innovation. For Korea, data are for 2013-15.

Source: OECD (2017f), OECD Science, Technology and Industry Scoreboard 2017. 


\section{Coping with labour shortages in SMEs}

Raising productivity in SMEs is essential to raise wages (Figure 2) and overcome the chronic labour shortages in smaller firms, which reflect low wages and poor working conditions. A recent poll by the Korea Small Business Institute reported that $80.5 \%$ of SMEs are experiencing difficulty finding employees, despite rising inflows of foreign workers. The number of foreigners allowed to enter Korea on work visas to be employed at SMEs rose from 479000 in 2012 to 549000 in 2016. Many Korean workers shun jobs in SMEs as being underpaid and difficult. A 2016 survey of university students by the Federation of Korean Industries reported that 32\% wanted to work for a big company and another 25\% preferred state-run institutions. Only $5 \%$ said they wanted to work at an SME. In addition, SMEs experience a high rate of labour turnover.

However, the labour shortage at SMEs is not due to a lack of available workers. The youth employment rate fell from 45\% in 2005 to 42\% in 2016, well below the OECD average of 53\% (Figure 14). In addition, the share of youth who were neither in employment nor in education or training (NEET) was high (Panel B), although the statistics do not capture the share of youth in Korea and other countries engaged in unofficial education. Low youth employment reflects the mismatch between the skills acquired in school and those demanded by firms due to an over-emphasis on higher education and a decline in the share of students choosing vocational high schools (Kim, 2015). Indeed, the share of high schools students enrolled in vocational high schools fell from $28 \%$ in 2006 to $19 \%$ in 2015, well below the $47 \%$ OECD average. Since the 2008 global crisis, students focus more on employability, reducing the share of high school graduates advancing to higher education from 83.8\% in 2008 to $69.8 \%$ in 2016, but it remains high.

Figure 14. Korea's youth employment rate is below the OECD average and the number of NEETs is high
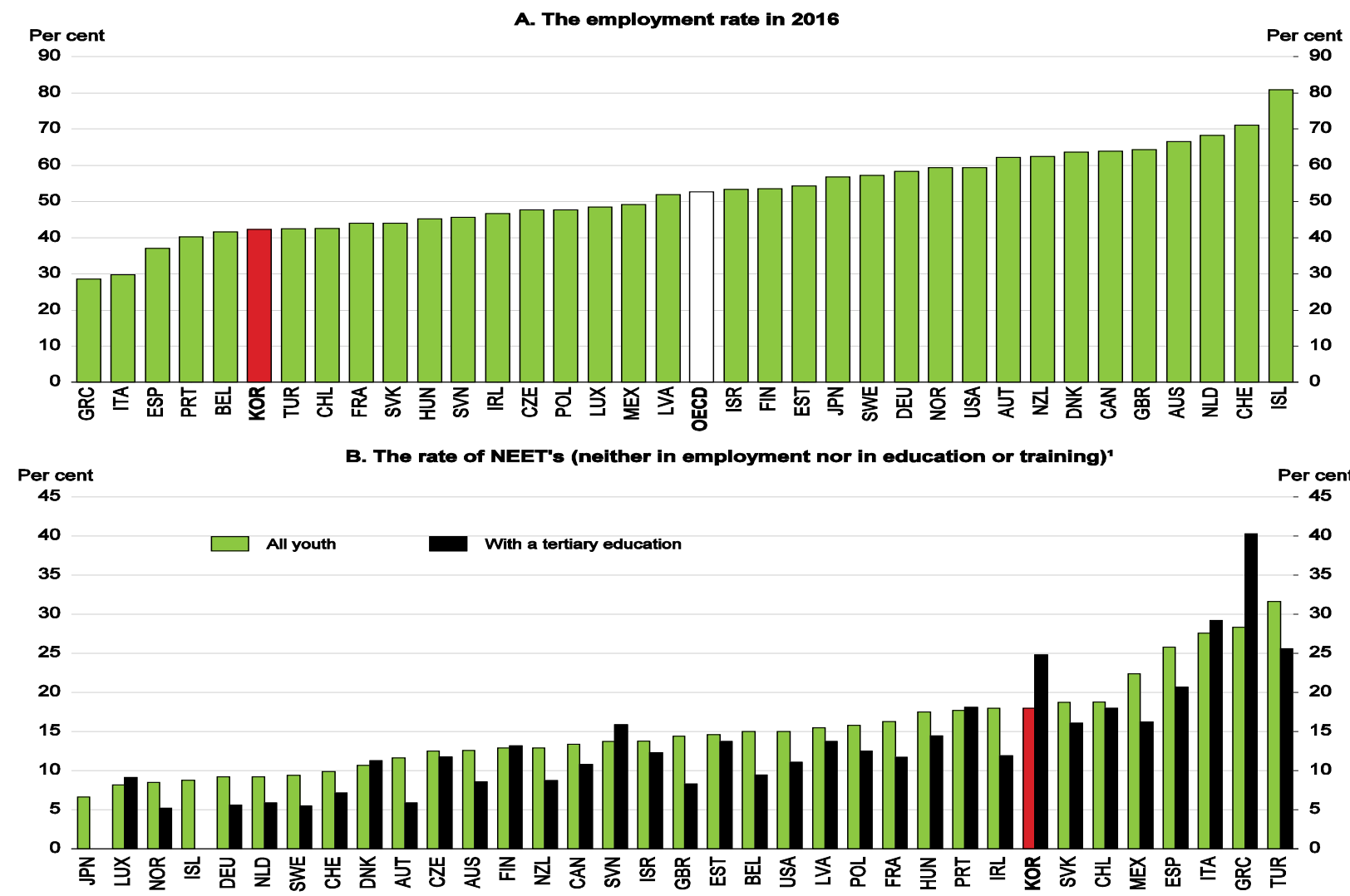

1. In 2013 for the 15-29 age group. It should be noted that data on programmes that straddle the boundary between upper secondary and post-secondary education [ISCED 4] are not available in Korea and 11 other OECD countries, leading to an overestimation of the number of youth classified as NEETs.

Source: OECD Employment and Labour Market Statistics (database); OECD (2015a), Education at a Glance 2015. 
Korea is one of the few countries in which the rate of NEETs for tertiary graduates (24.8\%) is higher than for the overall 15-29 age group (18.0\%) (Figure 14, Panel B). For many university graduates, waiting for an attractive job opportunity is better than being trapped in SMEs, where job security and wages are low. Periods of inactivity have a negative long-term effect on the employment and wage prospects of youth. The mismatch problem is high as well among youth who find jobs. For workers in the 15-29 age group, 37\% were in jobs that did not match their field of study and literacy skills (OECD, 2014).

\section{Reducing labour shortages in SMEs by addressing the mismatch in the labour market}

The low productivity and wage levels in SMEs discourage young people from accepting jobs at smaller companies, thus perpetuating low productivity. Breaking this vicious circle requires helping young people enter the labour market earlier through strengthened hands-on vocational education that begins at the secondary level. The government is changing the vocational education system at both the secondary and tertiary levels from a "theory-based" approach to "practice-based". It draws on 897 National Competency Standards developed by public and private experts that set out the knowledge, skills and attitudes that are required to perform a particular occupation. The government introduced Meister schools in 2008 to improve the negative social perception of vocational education. The Meister schools, which now total 46, allow students to pursue studies and internships simultaneously. In 2015, the government created work-study dual programmes at the secondary level. Finally, the government recently introduced "blind recruitment" in all 332 public institutions to ensure that people are hired based on their skills rather than other factors, such as academic achievements, family background and personal characteristics. The government is now encouraging private firms to follow suit.

A number of policies are needed to raise youth employment. First, breaking down labour market dualism would reduce the number of educated youth who prefer waiting for an attractive job opportunity to the stigma of non-regular employment, which is most prevalent in SMEs. Second, further enhancing the link between firms and all types of education is essential to address mismatch. Students in Meister schools and work-study dual programmes account for only $9 \%$ of vocational high school students. Third, the capacity of vocational high schools is too low to meet demand. The government should expand capacity to reach its target of raising the share of high school students enrolled in vocational schools to $29 \%$ by 2022. In addition, the introduction of blind recruitment may reduce discrimination. However, it may also discourage students from studying hard to qualify for admission to high level educational institutions.

\section{Ensuring adequate skills in the workforce of SMEs}

In addition to reducing the shortage of workers, it is necessary to ensure that education and training provide workers with enough skills, including digital skills, to achieving the government's goal of making SMEs drivers of innovation and digitalisation. SMEs are limited by a lack of skilled manpower and their capacity to train their workers is low compared to large firms (OECD, 2013a). In particular, promoting lifelong learning will be essential in this regard given the large gap in computer skills between generations. Indeed, the ability of youth (16-24) to solve problems using computers is one of the highest in the OECD, while that of older workers (55-64) is among the lowest (OECD, 2013b). However, the share of older workers receiving vocational education and training in Korea is low. In addition, Korea should expand the number of visas for employment at SMEs to allow high-skilled foreign workers, in addition to those with low skills, to fill shortages in SMEs. Finally, the tax code supports experts who directly engage in research activities at SME research institutes. They are allowed to deduct up to KRW 200000 (USD 185 000) per month for research expenses (Noh, 2017).

\section{Enhancing SME productivity by strengthening linkages with global markets}

The share of SMEs in Korea's total exports dropped from 21\% in 2009 to 18\% in 2015. SMEs have not benefited fully from the rapid growth of emerging economies and the proliferation of FTAs, nor have they 
become major players in global value chains (GVCs) in Asia. The share of small firms that participate in global value chains is the lowest in the OECD. Instead, SMEs are primarily focused on domestic demand: exports accounted for only 8.7\% of sales of manufactured products by SMEs in 2015 (Table 4). In addition, the proportion of retail sales has declined, while sales to other SMEs and to large firms have risen, reflecting the growing importance of subcontracting. In addition, SMEs' indirect contribution to exports appears limited: value added from domestic services, where SMEs account for $90 \%$ of employment, accounted for only $26.0 \%$ of gross exports over $2010-14$, well below the $40 \%$ OECD average (Figure 15). Moreover, Korea is one of the few countries to record a significant decline since the late 1990s.

Table 4. SMEs are focused primarily on domestic markets

Percentage of sales of manufactured products by customer

\begin{tabular}{lcccccccc}
\hline & Exports & \multicolumn{9}{c}{ Domestic sales } & Total \\
\cline { 3 - 7 } & & $\begin{array}{c}\text { Sales to large } \\
\text { firms }\end{array}$ & $\begin{array}{c}\text { Sales to other } \\
\text { SMEs }\end{array}$ & $\begin{array}{c}\text { Sales to public } \\
\text { institutions }\end{array}$ & $\begin{array}{c}\text { Retail } \\
\text { sales }\end{array}$ & Sub-total & 100.0 \\
\hline 2004 & 8.4 & 29.8 & 46.1 & 3.6 & 12.1 & 91.6 & 100.0 \\
2015 & 8.7 & 29.9 & 47.6 & 4.9 & 8.9 & 91.3 & -0.3 & 0.0 \\
\hline Difference & 0.3 & 0.1 & 1.5 & 1.3 & -3.2 & -0.3 & \\
\hline
\end{tabular}

Source: Statistics Korea, KOSIS database.

Exports provide an opportunity for expansion and job creation (Moon, 2017). According to a government survey of more than 2700 SMEs, those that are export-oriented (defined as a firm in which direct exports account for at least $29.8 \%$ of their total sales) are more focused on R\&D, which accounted for $10.7 \%$ of their sales, compared to less than 3\% for all SMEs. Exports by SMEs could be increased by: $i$ ) better utilising digital platforms to enhance linkages with the global market; ii) making greater use of ICT convergence technology, as noted above; iii) increasing participation in high value-added GVCs, in part by eliminating trade and investment barriers; and iv) developing trade in services.

Figure 15. The contribution of services to exports is relatively low in Korea

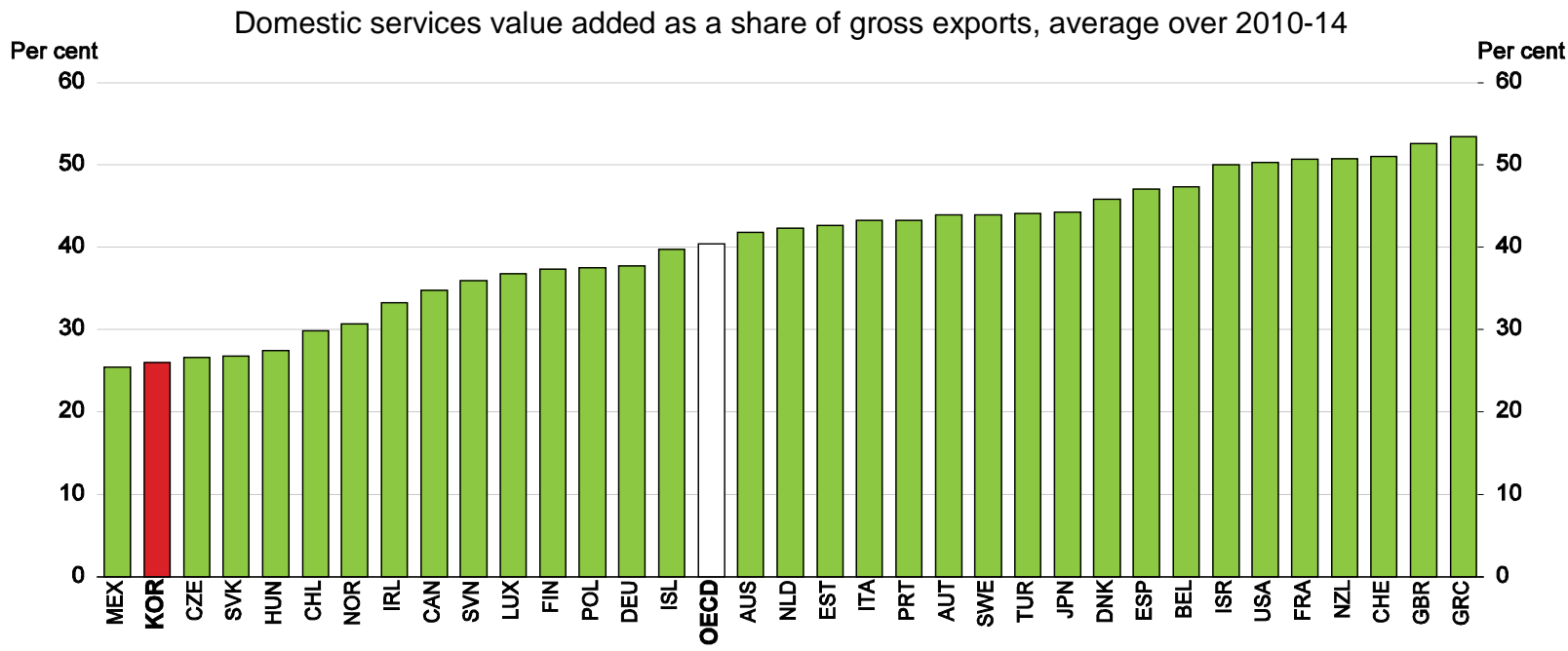

Source: OECD-WTO: Statistics on Trade in Value Added (database).

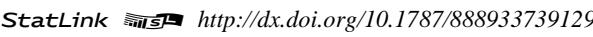

Digital platforms provide new opportunities for small enterprises to tap into foreign markets (OECD, 2016a). However, only 12.4\% of exporting SMEs in Korea used e-commerce, according to a government survey (Chang and Lee, 2017), as firms rely more on face-to-face contact. In companies with more than 31 years of export experience, the rate of e-commerce utilisation is only 4\%. SME exporters give a number of reasons for not using e-commerce: i) they are not interested in it (27\%); ii) they lack the professional 
manpower to use it (26\%); iii) they are not familiar with it (25\%); and iv) the cost of constructing such systems is too high (15\%). Moreover, among those using e-commerce, the major platform used is the homepage of the exporting company (49\%), with smaller roles for globally popular platforms (29\%) and the export target country's major platform (14\%). Policies to educate SMEs about the possibilities of using ecommerce to export, help them train the necessary manpower and reduce the cost of implementing such systems would help increase SME exports (OECD, 2017e and 2017g) and promote "global start-ups" (Box 3). The government's SME Export Support Centre should develop an on-line platform to facilitate contacts between SMEs and overseas buyers. However, success in exporting ultimately depends on overcoming the problems that hamper productivity in Korean SMEs that are discussed in this paper.

\section{Box 3. Global start-ups}

"Global start-ups", a term applied to young firms heavily involved in international trade, have made large contributions to innovation and employment, two top priorities of the government. In 2016, 490 "innovative start-ups" that were less than seven years old were surveyed (Lee et al., 2017). Of them, 124 are classified as global start-ups based on three criteria: $i)$ they entered overseas markets within three years after their establishment; ii) they are active in at least two foreign countries through, for example, joint ventures or strategic alliances; and iii) their exports account for more than $25 \%$ of total sales. On average, they exported some $50 \%$ more than other innovative startups.

Global start-ups achieve more employment growth, raising the number of employees by seven over 2009-15, a larger increase than in enterprises that attract venture capital investment (but may not qualify as global start-ups). Meanwhile, non-global start-ups increased employment by five persons. The ability of global start-ups to produce internationally-competitive products from the outset suggests relatively strong innovation capabilities. The share of their products using breakthrough technology not seen before in Korea or the world was $28.5 \%$ compared to $19.0 \%$ for non-global start-ups.

Only $38 \%$ of the global start-ups participated in government programmes providing assistance. Instead, they relied primarily on private-sector networks, such as their personal contacts and domestic trading companies, which are able to provide objective evaluation and sufficient support. This suggests that private-sector experts with a proven track record are better able to provide the necessary assistance to start-ups. Moreover, the complexity of joining government programmes, which tend to require a record of success, discourages the participation of startups. Improving the programmes would allow them to complement the private-sector networks of the start-ups and increase the number of innovative start-ups that turn into global start-ups.

Korea is active in "Factory Asia", as the import content of its exports was 38\% in 2014, compared to the OECD average of $30 \%$. A quarter of export-oriented SMEs have overseas production bases, of which three-quarters are participating in GVCs. Firms that participate in GVCs are more productive than nonparticipating firms. However, the productivity gap is much bigger among large firms than among small firms, as more than half of Korea's SME exporters are concentrated in low value-added work such as finished goods assembly (32.6\%) and parts production (20.2\%) (Kim et al., 2016).

Lowering Korea's barriers to trade and investment, which were the second highest in the OECD in 2013, would promote the participation of SMEs in high value-added GVCs. Given the concentration of SMEs in services, increasing trade in services would help boost their productivity. Many of the key trade barriers affect services. Korea's service trade restrictiveness index is below the OECD average in 14 out of 22 sectors but still above it in some sectors that play key roles in GVCs, such as telecom, legal and accounting services and rail freight transport (Figure 16). In addition, enhancing institutional transparency and regulatory reform (see below) and harmonising standards and technical regulations would reduce regulatory costs.

Increasing SMEs' direct exports of services would also be beneficial, although it would be a challenge given that Korea's service sector is relatively undeveloped. Export-led development has siphoned capital, ta4lent and other resources away from services and toward manufacturing. Services accounted for $58.6 \%$ of Korean GDP in 2017, well below the OECD average, and accounted for 70.1\% of employment (Figure 17). The share of the service sector in employment has been on an upward trend, while its share of output has been stagnant. The $46 \%$ gap in the level of economy-wide labour productivity between Korea and the top 
half of OECD countries is largely explained by low productivity in services, which was $44 \%$ of that in manufacturing in 2017, compared to an average of $84 \%$ in the OECD (Panel C). Services also play a relatively small role in international trade. While Korea was the world's eighth-largest exporter of goods in 2016, it ranked $17^{\text {th }}$ in service exports.

Figure 16. Korea should reduce barriers to trade in key services

$$
\text { In } 2017 \text { or latest year }{ }^{1}
$$

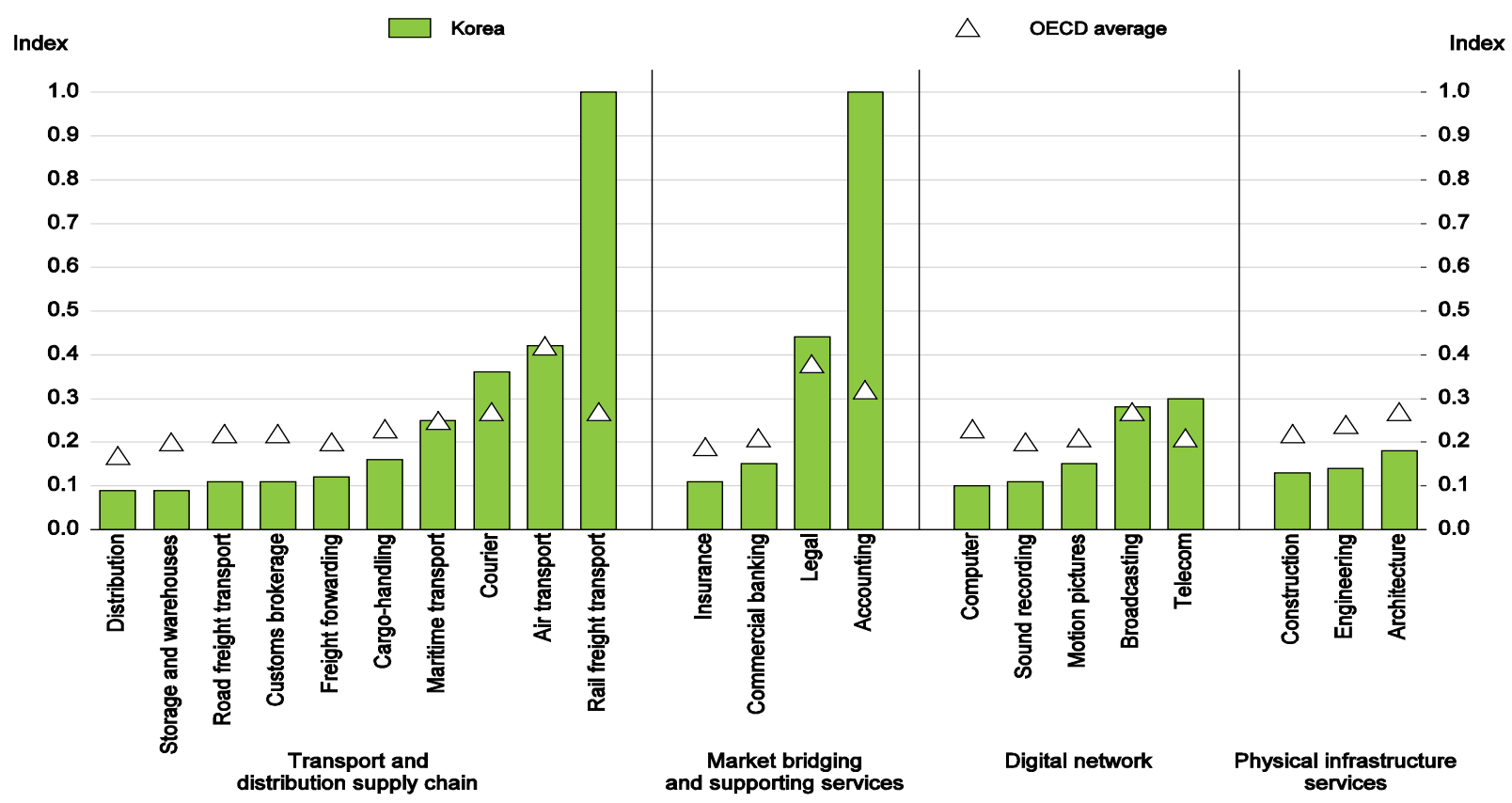

1. The STRI indices take values between zero and one, one being the most restrictive. The STRI database records measures taken on a "Most Favoured Nation" basis while excluding preferential trade agreements.

Source: OECD Services Trade Restrictiveness Index (database).

StatLink 角四 http://dx.doi.org/10.1787/888933739148

Figure 17. Service sector productivity is low in Korea

In $2017^{1}$
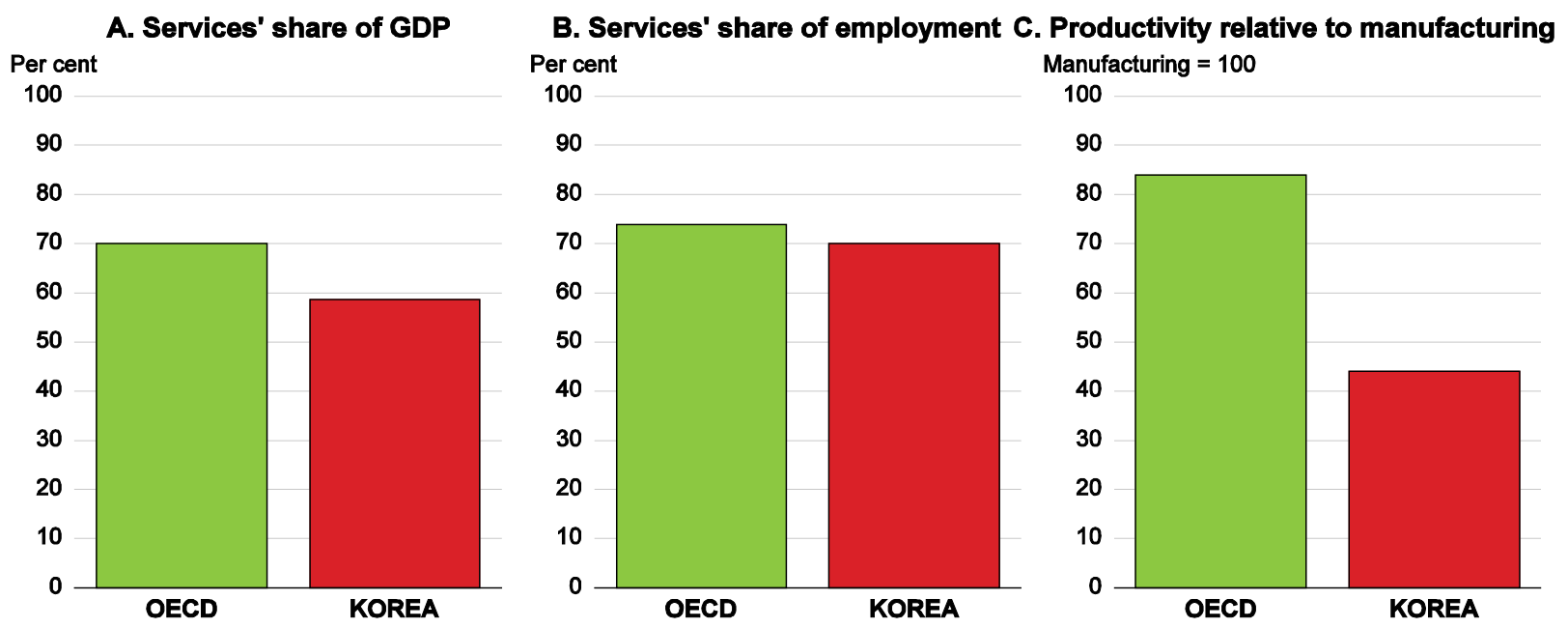

1. Based on 2010 prices for value added.

Source: OECD National Accounts Statistics (database); OECD Structural Analysis Statistics (database). 
The first priority to increase SME participation in global trade would be to raise the share of domestic services value added in gross exports from its current low level (Figure 15). However, this requires addressing the factors that keep its productivity low (Jones, 2009). One reason is that services account for only $8 \%$ of Korea's business expenditure on R\&D, the lowest in the OECD (Figure 18). Moreover, services accounted for only $3.4 \%$ of public R\&D spending in 2017. The government aims to raise the share to $6 \%$ during the next five years. In addition, the measures discussed above to make the R\&D tax credit more effective for SMEs would be beneficial.

Figure 18. Korea R\&D in services is the lowest in the OECD

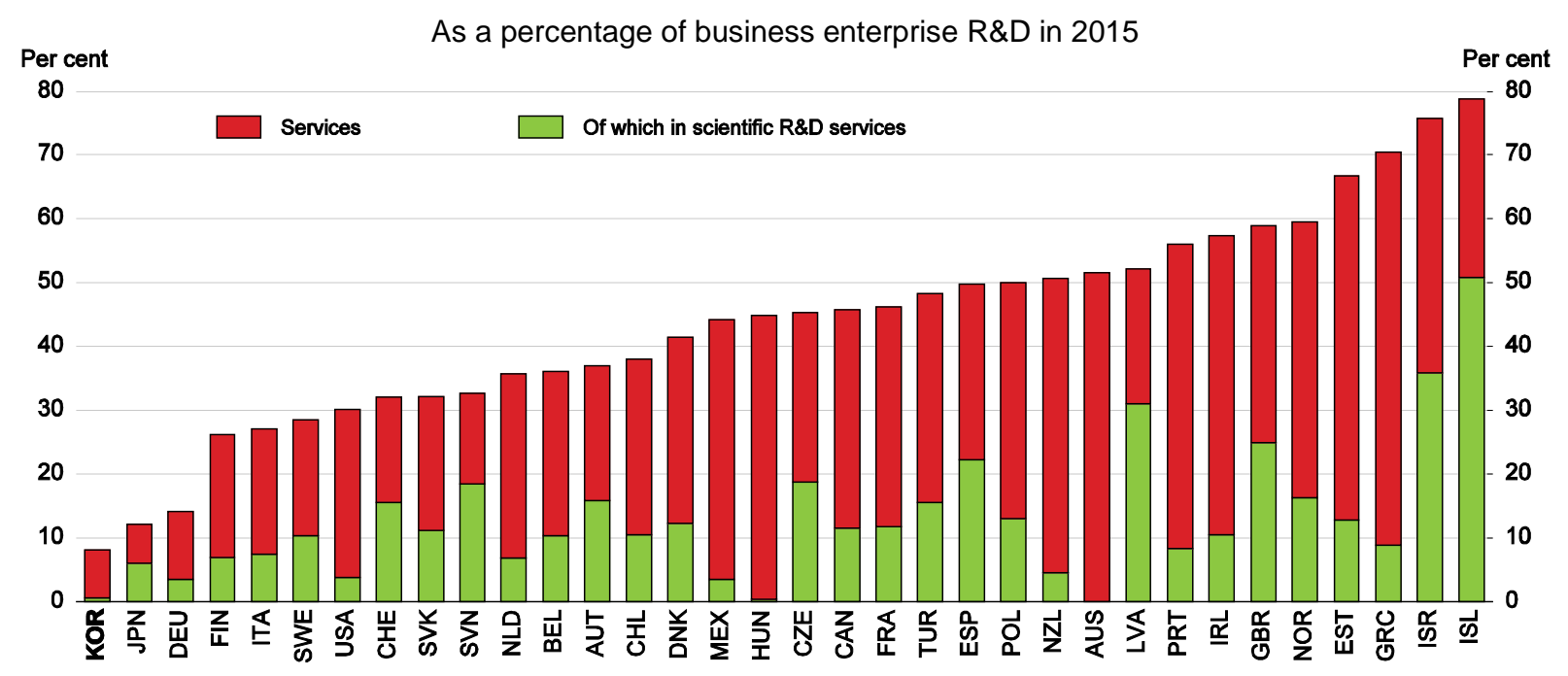

Source: OECD (2017f).

StatLink 角西 http://dx.doi.org/10.1787/888933739186

\section{An ecosystem to promote dynamic SMEs}

\section{Regulatory reform to reduce the burden on SMEs and create new opportunities}

In 2013, it was estimated that 8921 regulations - 59\% of the total number -- applied to SMEs (Table 5), reflecting their prevalence in services. Economic regulations covering entry, price, trading and quality, which can distort the functioning of markets, accounted for about one-third of the regulations. Another third were social regulations on environment, industrial accidents, consumer safety and social discrimination. In addition more than 1800 SME regulations applied to the creation of enterprises (Panel B). In sum, the creation of SMEs and their business activities are subject to a large number of regulations. As in other countries, regulation is a key obstacle to the emergence of dynamic SMEs (OECD, 2016b). In line with its goal of making SMEs the driver of the fourth industrial revolution, the government plans to lower the cost of starting firms and reduce the regulatory burden on existing firms. Potential entrepreneurs in Korea face high start-up costs at $14.6 \%$ of per capita gross national income, four times higher than the 3.1\% OECD average (World Bank Group, 2017). It is also far above other Asian economies such as China (0.6\%) and Chinese Taipei (2.0\%).

One major obstacle to firm creation is Korea's positive-type regulatory system, which prohibits everything except what is specifically allowed. One step towards a negative-type regulatory system (which allows everything except what is specifically prohibited) is the government's plan to liberalise regulations in a specific geographic areas and industries, notably ICT (Office for Government Policy Coordination Prime Minister's Secretariat, 2017). This is to be accompanied by "regulatory sandboxes", which allows the temporary provision of licenses in sectors using new technology (World Bank Group, 2017). This approach is being used in a number of countries, including Japan, which will soon apply it to automated driving and 
long-range drones (Nikkei Asian Review, 2017). An initial step in this regard in Korea was a 2015 law that created a type of regulatory sandbox to promote the ICT sector. However, by mid-2017, only three cases had been dealt with and it took an average of 133 days to receive temporary permission (Choi et al., 2017). Using regulatory sandboxes effectively would help Korea shift to a comprehensive negative-list regulatory system.

Table 5. There are a large number of economic regulations on SMEs ${ }^{1}$

A. By type of regulation (in 2013)

\begin{tabular}{|c|c|c|c|}
\hline \multicolumn{2}{|c|}{ Type of regulation } & \multirow{2}{*}{$\frac{\text { Number of regulations }}{154}$} & \multirow{2}{*}{$\frac{\text { Per cent of total }}{1.9}$} \\
\hline \multirow{5}{*}{ Economic regulations } & Entry & & \\
\hline & Price & 1012 & 12.2 \\
\hline & Trading & 1092 & 13.2 \\
\hline & Quality & 606 & 7.3 \\
\hline & Sub-total & 2864 & 34.5 \\
\hline \multirow{5}{*}{ Social regulations } & Environment & 806 & 9.7 \\
\hline & Industrial accidents & 423 & 5.1 \\
\hline & Consumer safety & 1440 & 17.4 \\
\hline & Social discrimination & 279 & 3.4 \\
\hline & Sub-total & 2948 & 35.6 \\
\hline \multicolumn{2}{|c|}{ Administration regulations } & 2479 & 29.9 \\
\hline \multicolumn{2}{|c|}{ Total } & 8291 & 100.0 \\
\hline
\end{tabular}

B. Economic regulations on SMEs by type of activity (in 2013)

\begin{tabular}{|c|c|c|c|}
\hline \multicolumn{2}{|c|}{ Type of regulation } & $\begin{array}{c}\text { Number of regulations } \\
1247\end{array}$ & $\frac{\text { Per cent of total }}{15.0}$ \\
\hline Creating an enternrice & Building & 310 & 3.7 \\
\hline & Sub-total & 1821 & 22.0 \\
\hline \multirow{8}{*}{ Business activities } & Administration & 2143 & 25.8 \\
\hline & Production & 1075 & 13.0 \\
\hline & Finance & 442 & 5.3 \\
\hline & Safety & 407 & 4.9 \\
\hline & Environment & 343 & 4.1 \\
\hline & International trade & 208 & 2.5 \\
\hline & Technology & 62 & 0.7 \\
\hline & Sub-total & 6227 & 75.1 \\
\hline Family business succession & & 65 & 0.8 \\
\hline Closure \& company clean-up & & 89 & 1.1 \\
\hline Total & & 8291 & 100.0 \\
\hline
\end{tabular}

1. Regulations either legally limited to SMEs, pertaining to sectors where practically all firms are SMEs or cited by SME associations as important to their member firms.

Source: Cho and Kim (2013).

A second obstacle is that the regulatory burden tends to be relatively greater on SMEs than on large enterprises (OECD, 2017h). Indeed, the uncertainty, complexity and inconsistency of regulation are sometimes greater problems for SMEs, which have fewer resources than large firms, than the regulation itself. Of the 8291 regulations applied to SMEs in 2013, only 1.7\% allowed differential treatment for SMEs. A number of countries are taking steps to ease regulatory burdens on SMEs. For example, the United States introduced the "Regulatory Flexibility Act" in 1980 to allow differences in regulations applied to SMEs and large firms. Korea should make efforts to reduce the burden of regulatory compliance, focusing on SMEs, while ensuring that key economic and social objectives, such as those related to the environment, safety and labour rights, are met.

Protecting SMEs by strengthening the stringency of regulation on large enterprises should be avoided, as the overall economic effect would be negative. General equilibrium models suggest that the positive effect 
of regulatory reform is greatest when it applies to both large enterprises and SMEs (Jung, 2016). Moreover, the positive impact of regulatory reform that is applied only to large firms is greater than that applied only to SMEs. Similarly, the negative effect of regulation imposed only on large firms is more negative than regulation imposed only on SMEs. In short, using regulations to improve the position of SMEs relative to large enterprises is counter-productive, while trying to eliminate unfair business practices. In general, the objective should be to remove regulations that inhibit competition by large firms and SMEs, while achieving social objectives.

\section{Using public procurement to assist SMEs}

SMEs are supported through a broad range of programmes in Korea to boost their share of public procurement of goods and services. Indeed, the law sets a target of 50\% for SMEs' share of total public procurement, which accounts for a $21.7 \%$ of government spending. SMEs captured $54 \%$ of contracts awarded through competition in 2014, up from 30\% in 2009. An OECD study concluded that public procurement in Korea is "overly focused on SMEs, to the exclusion of large suppliers” (OECD, 2016f).

Public procurement policies to benefit SMEs have the unintended side effect of increasing dependency on public support and slowing productivity gains. SMEs chosen for public procurement in 2009 had significantly lower productivity in 2011 and a greater chance of survival than other firms (W. Chang, 2017). Public procurement policies thus result in a moral hazard by encouraging SMEs to depend on the procurement market for survival without improving their productivity to the level demanded by the market. The government should reduce this distortion by tightening the screening process for SMEs involved in public procurement and monitoring their performance. In order to promote innovation by SMEs, government procurement programmes for SMEs and start-ups are focusing more on technologically-advanced products.

\section{Addressing other obstacles to the development of SMEs}

Making SMEs a driver of innovation to achieve the fourth industrial revolution requires shifting from a "fast-follower" approach that has driven Korea's catch-up to a "first-mover" strategy. Under the fastfollower model, the government has supported winners who were able to compete in international markets. The government's science, technology, industrial and education policies have focused on repeating past successes, while failing to create an innovative ecosystem (Lee and Choi, 2017). Bureaucratic decisions to select and support national champions have interfered with technological decisions and stifle innovation. The costs associated with administrative burdens and red tape are relatively higher for SMEs than for large enterprises, thus hamstringing innovation in SMEs. Shifting to a fast-follower strategy requires a fundamental shift in government strategy, as well as in the education system and corporate practices. In sum, direct interference by the government should be reduced.

The criteria to receive special treatment as an SME, which were based on the number of regular workers, sales, capital and total assets until 2015 (Box 2), created disincentives for SMEs to grow and lose their preferential treatment. This led to a "bunching effect" as firms stopped expanding once they reached the various thresholds in order to remain eligible for government support (the "Peter Pan syndrome"). This led to a new definition of SMEs in 2015 that is based on total assets and sales. However, there is still bunching as SMEs limit assets and sales to stay below the threshold. One strategy of enterprises that want to maintain SME status is to split the firm in two (H. Kim, 2017). The disincentive to growth also applies to mid-size firms, which must keep total assets below KRW 10 trillion to continue receiving special benefits.

Special tax treatment for SMEs is one of the major incentives that discourages firms from growing and graduating from SME status, which has a negative effect on a country's growth (OECD, 2015c). Moreover, it also gives incentives to artificially split up into different businesses to continue benefitting from the preferential tax treatment. Tax support for SMEs in Korea is high and its coverage is broad compared to 
other OECD countries, and continues to favour manufacturing. In most OECD countries, preferential tax treatment applies only to firms with less than 50 employees, while in Korea all SMEs, which account for 99.8\% of companies, and mid-size companies, are eligible. A range of tax credits are offered to firms that, for example, make investments that create jobs, increase their employment of regular workers and convert non-regular workers to regular status. Reducing the range of SMEs receiving preferential tax benefits would weaken the Peter Pan syndrome. The negative effect on company growth from government subsidies to specific firm classes should be reduced by scaling back their generosity and phasing out benefits gradually for firms that graduate from SME or mid-size firm status.

Subcontracting relationships (2018 OECD Economic Survey of Korea) have a big impact on SME performance, given that they account for a large share of SME sales (Table 4). The sales and total assets of SMEs that subcontract with large and mid-size enterprises are larger than for SMEs that do not subcontract. Indeed, the sales and assets of the large companies are correlated with those of the subcontracting SMEs. However, the increase in SMEs' sales and assets is not accompanied by a rise in their operating profit ratio (Chang and Woo, 2015). This reflects their generally weak bargaining power relative to large firms. Even among mid-size firms, 23\% reported that they had been asked to reduce their delivery prices by $3 \%$ to $5 \%$ in 2015 (Association of High Potential Enterprises of Korea, 2017). This has negative implications for productivity as subcontracting SMEs and mid-sized firms have little incentive to become more efficient. The virtuous circle of reinvesting profits to become more productive is broken. This also has implications for government support for SMEs, which may be passed on to the large firms (W. Chang, 2018). This so-called "straw effect" is statistically significant in the ICT sector, where the government is increasing SME support to promote the fourth industrial revolution.

\section{Promoting entrepreneurship to increase the number of start-ups}

Increasing enterprise creation boosts "labour productivity growth, with evidence pointing to a correlation between start-up and churn rates, and productivity growth, although, the impact on recorded labour productivity growth may not be immediate” (OECD, 2016b). Korea was ranked $21^{\text {st }}$ in the OECD according to the 2018 Global Entrepreneurship Index (Figure 19).

Figure 19. Korea is ranked $21^{\text {st }}$ in the 2018 Global Entrepreneurship Index

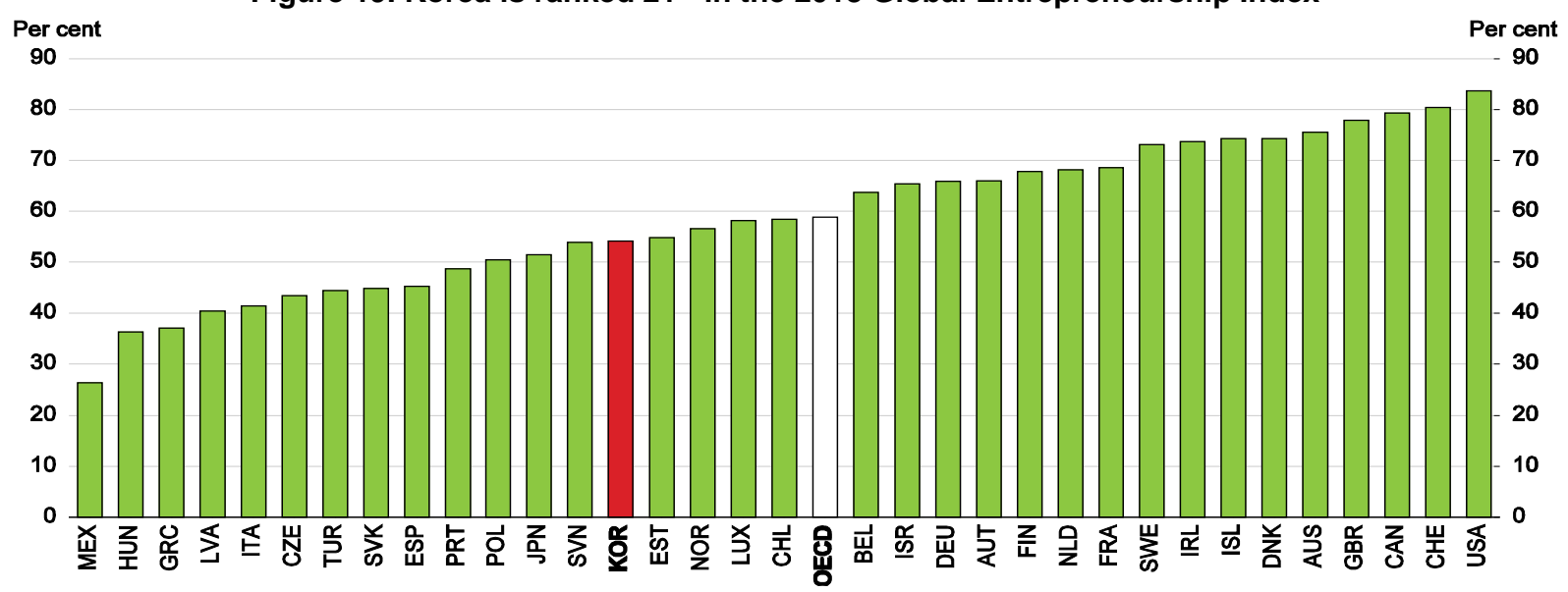

Source: Global Entrepreneurship Development Institute (2018), Global Entrepreneurship Index 2018.

StatLink त्ताइ http://dx.doi.org/10.1787/888933739205

In the Global Entrepreneurship Monitor international survey, Korea ranked $37^{\text {th }}$ among the 60 countries surveyed. Moreover, only $34 \%$ of the Korean population has a favourable perception of start-ups, far below the OECD average of 49\% (OECD, 2014). These indicators suggest weaknesses in entrepreneurship that should be addressed to promote inclusive growth (Park, 2017). In November 2017, the government launched 
a "Plan to Create an Ecosystem to Nurture Innovative Start-ups" (Box 4), which is similar to the 2013 "Measures to Improve the Venture Start-up Ecosystem” (2014 OECD Economic Survey of Korea). Both include tax incentives for business angels, public-private venture capital funds, measures to promote M\&As and strengthening KOSDAQ.

\section{Box 4. A government plan to create an ecosystem to nurture innovative start-ups}

The plan announced by the government in November 2017 set three goals and policies to achieve them.

1. Creating a start-up-friendly environment to foster entrepreneurship

- Support talented individuals launching diverse start-ups: i) encourage spin-offs from existing firms by introducing a "start-up leave" system, which allows entrepreneurs to return to employment in case of failure; and ii) allow professors in universities to have more flexible employment arrangements to encourage start-ups.

- Transform the venture start-up support system into a private sector-driven system. Utilise the Tech Incubator Programme for Start-ups (TIPS) as part of the government's overall policy on start-ups.

- Provide support during the seed stage of start-ups, such as office space and online and offline networking opportunities. Utilise the Pangyo Techno Valley, government properties and public institutions as "makerspaces" to facilitate the exchange of ideas and commercialisation of innovative ideas.

- Assist start-ups during their developmental stages, including financing, participation in public procurement, securing markets, including overseas, thereby helping them survive the so-called "Valley of Death" and grow into strong mid-size enterprises.

\section{Expanding financing opportunities and tax incentives}

- Set up an "innovation adventure fund" worth KRW 10 trillion (USD 9.3 billion): i) the public sector will contribute KRW 3 trillion through fiscal expenditure and policy-based loans and the private sector will provide KRW 7 trillion; and ii) provide a comprehensive funding package for venture business throughout different stages, from commercialisation of ideas to market launch, and from M\&A to business reorganisation.

- Promote technology financing based on the firm's profitability and the future value of the technology. Provide more educational programmes on technology financing, for example at the Korea Banking Institute.

- Diversify tax incentives for start-up investment to attract investment by a broader group of investors: i) double the amount of the angel investment tax exemption that is $100 \%$ deductible from the current level of KRW 15 million (USD 13 893); ii) reintroduce the tax exemption for gains from stock options, iii) increase the tax exemption for employee stock ownership from KRW 4 million to KRW 15 million; and iv) introduce tax incentives for investment in start-up investment associations to encourage investment in small amounts.

\section{Establishing a virtuous cycle between start-ups and investment}

- Gradually phase out joint surety (guarantees), which pose a heavy burden on entrepreneurs' family and friends in the case of bankruptcy, making it difficult to re-start the company. Policy-based financing institutions will abolish it within the first half of 2018 and private institutions will phase it out gradually.

- Facilitate Initial Public Offerings (IPOs) and M\&As: i) strengthen the independence of the KOSDAQ Market Committee to boost the KOSDAQ and KONEX markets; ii) encourage investment from pension funds, iii) boost incentives for large enterprises to take part in M\&As; and iv) attract foreign venture capital investment in domestic M\&As.

- Prepare measures to prevent technology theft: launch a task force at the Korea Fair Trade Commission this year and expand its investigative mandate over technology theft.

Source: Ministry of Strategy and Finance (2017), Press Release (2 November).

\section{Promoting opportunities for female entrepreneurs}

Entrepreneurial opportunities in Korea for women are relatively limited compared to men. The share of female entrepreneurs (defined as self-employed persons with employees and own account workers) was 14\% in 2016, compared to the 10\% OECD average. However, it was well below the $26 \%$ rate for Korean men, leading to the third-largest gender gap in entrepreneurship in the OECD (Figure 20). 
Figure 20. The gender gap in the entrepreneurship rate in Korea is high

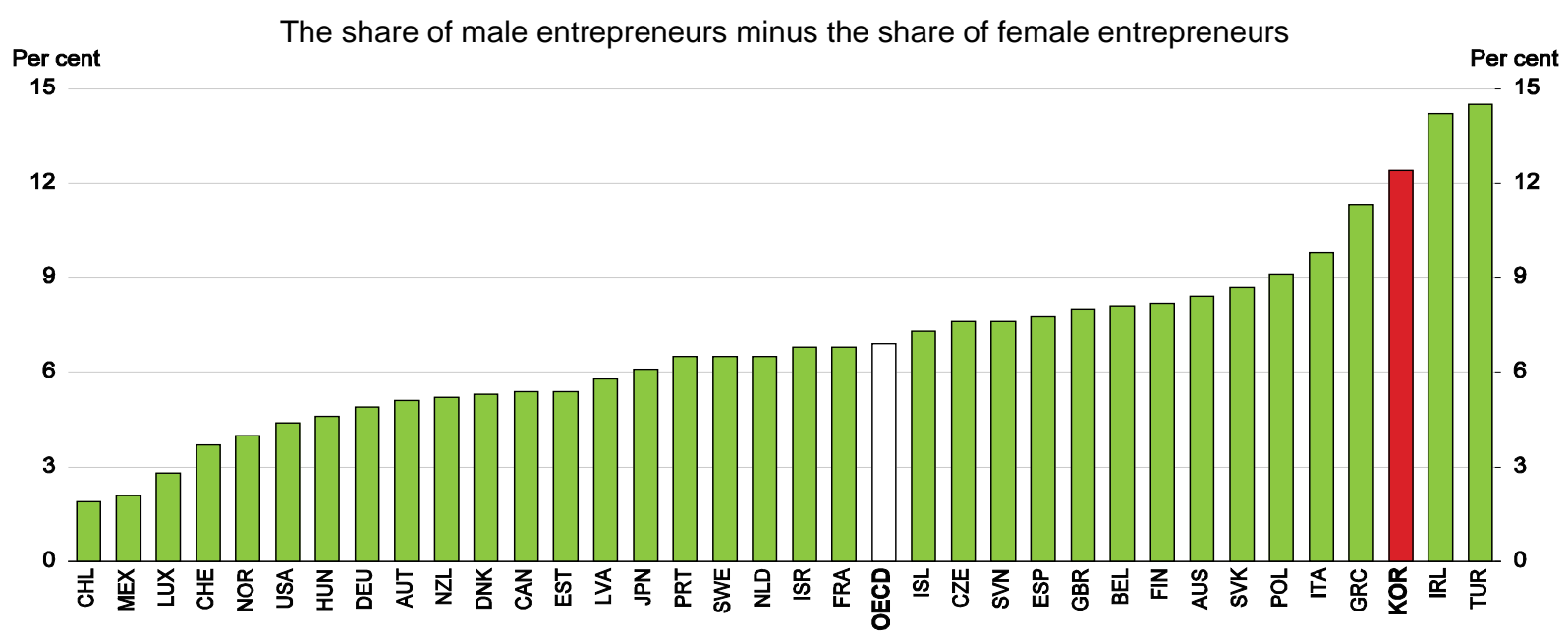

1. Defined as self-employed with employees and self-account workers as a share of total employed.

Source: OECD (2017c), OECD Entrepreneurship at a Glance 2017.

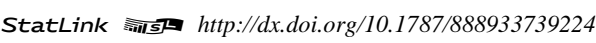

Female entrepreneurs cited six key disadvantages in a 2015 survey: $i)$ balancing work and family responsibilities (80\%, i.e. only $20 \%$ did not feel any difficulty); ii) adapting to male-centred business practices (76\%); iii) obtaining financing (70\%); iv) loss of business opportunities due to their perceived passive management (69\%); v) discrimination against women in business (69\%); and vi) operating in maleoriented networks that limit participation by women (Korea Women's Entrepreneurship Association, 2015). Regarding financing, the initial capital of female entrepreneurs in 2015 was only $62 \%$ of that of men, which is close to the gender wage gap. Difficulties in financing have reduced opportunities for female entrepreneurs to enter high value-added industries, as discussed above.

Developing entrepreneurship opportunities for women is a priority to achieve inclusive growth. Entrepreneurship enables women to avoid the dualistic labour market, which leads to the largest gender wage gap in the OECD (37\%), reflecting the fact that $41 \%$ of female employees are non-regular workers. The attractiveness of starting one's own business has increased during the past few years of relatively slow growth and slack labour market conditions. Although start-ups by women in Korea rate highly in terms of job creation and business stability (Korea Women's Entrepreneurship Association, 2015), female entrepreneurs are concentrated in basic livelihood sectors, such as health and social welfare, accommodations and restaurants, other personal services and educational services (Figure 21), reflecting in part their more limited access to financing and their educational background. Such sectors are characterised by fierce competition and comparatively high failure rates. Relatively few female entrepreneurs create firms in manufacturing or high value-added sectors such as finance and insurance and science and technology. In addition, nine out of ten firms started by female entrepreneurs have less than ten employees.

The government is investing in female entrepreneurs, using a fund aimed at women. The fund, which totalled KRW 54 billion (USD 50 million) over 2014-17 is to be increased to KRW 90 billion over 2018-22. One of the criteria for firms to qualify for support from the fund for female entrepreneurs is to have women account for 35\% of their employees, even if the entrepreneur is male. However, only 114 of the 712 persons receiving support from the Start-up Academy Programme in 2016 were women (Table 6). Female start-up's share of support for exports, funding and R\&D was even smaller, though increases were planned for 2017. At a minimum, support for female start-ups should match that for male start-ups and the number of women receiving such support should be increased. Government support should be combined with greater marketbased financing (see below). Experience shows that to increase the number of start-ups by women, it is not enough to simply encourage more women to start companies. A key is to have more women join venture capital firms (Raina, 2016). 
Figure 21. Female entrepreneurs are concentrated in certain industries

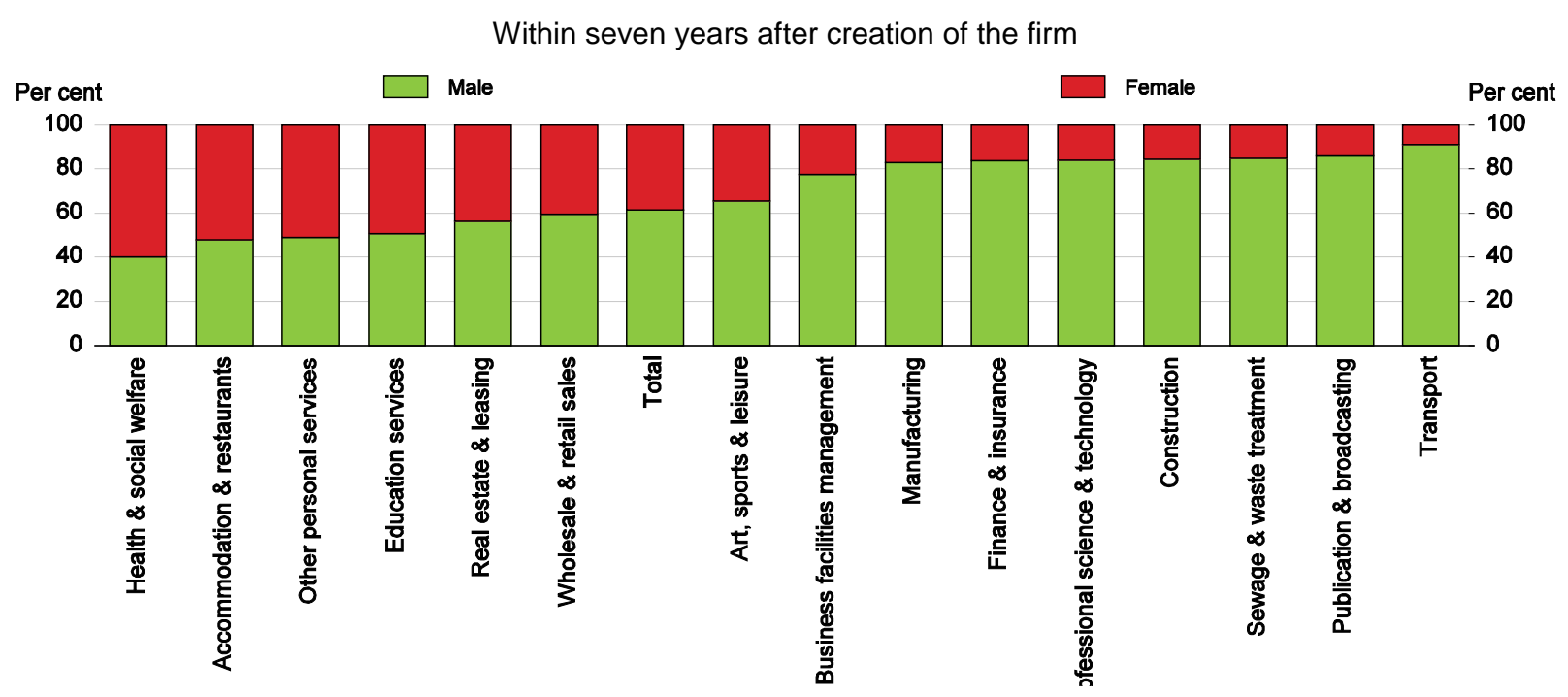

Source: Ministry of SMEs and Start-ups (2018), 2017 Survey on the Status of Start-ups.

StatLink ग्ना15 http://dx.doi.org/10.1787/888933739262

Table 6. Government support for female entrepreneurs is low

\begin{tabular}{|l|cccc|}
\hline & $\begin{array}{c}\text { R\&D } \\
\text { support } \\
\text { (billion won) }\end{array}$ & $\begin{array}{c}\text { Funding } \\
\text { support } \\
\text { (billion won) }\end{array}$ & $\begin{array}{c}\text { Export } \\
\text { support } \\
\text { (number of } \\
\text { firms) }\end{array}$ & $\begin{array}{c}\text { Support from the Start- } \\
\text { up Academy Programme } \\
\text { (number of persons) }\end{array}$ \\
\hline $\begin{array}{l}\text { Government support for female entrepreneurs in } \\
2016\end{array}$ & 61.3 & 482.6 & 1559 & 114 \\
$\begin{array}{l}\text { Share of total support } \\
\text { Government support for female entrepreneurs in } \\
2017\end{array}$ & 6.5 & 10.7 & 15.0 & 16.0 \\
Share of total support & 75.8 & 430.2 & 2083 & 266 \\
\hline
\end{tabular}

Source: Ministry of SMEs and Start-ups (2017c), Promotion Plan for Female's Business Activities.

\section{Strengthening the entrepreneurial spirit of youth}

The entrepreneurial spirit of Korean youth has dimmed following the venture capital boom of the late 1990s. In the early 2000s, 32\% of the chief executive officers of Korean venture companies were in the 20 to 30 age group, but this share fell to $10 \%$ in 2010 . Korea had the second-lowest percentage of young people age 18 to 34 involved in early-stage entrepreneurship in the OECD in 2012 (Figure 22). Youth were held back by a seeming absence of opportunities, the lack of the necessary knowledge and skills to start a firm and a fear of failure. This weakening of youth's entrepreneurial spirit will frustrate Korea's objective of achieving growth led by SMEs and start-ups. Measures to improve attitudes toward entrepreneurship are thus a priority (Kim, 2014).

First, it is essential to improve the image of entrepreneurship and the capacity of youth to become entrepreneurs through education beginning in primary school. Korea has been running the "Bizcool" programme in primary and lower secondary schools since 2002, but it covered only 15 primary and ten middle schools in 2013. Entrepreneurship education is being introduced as a regular course in all primary and secondary schools in 2018, including after-school "start-up classrooms". The programme should draw on the OECD's Entrepreneurship 360 project. The Start-up Leading University (SLU) programme, which has a significant impact, is currently run by three separate ministries. Management should be combined in one ministry. In addition, leaves for students creating a start-up should be extended and more academic credit should be given for those engaged in entrepreneurial activities. 
Figure 22. Korea's entrepreneurship rate for youth is far below the OECD average

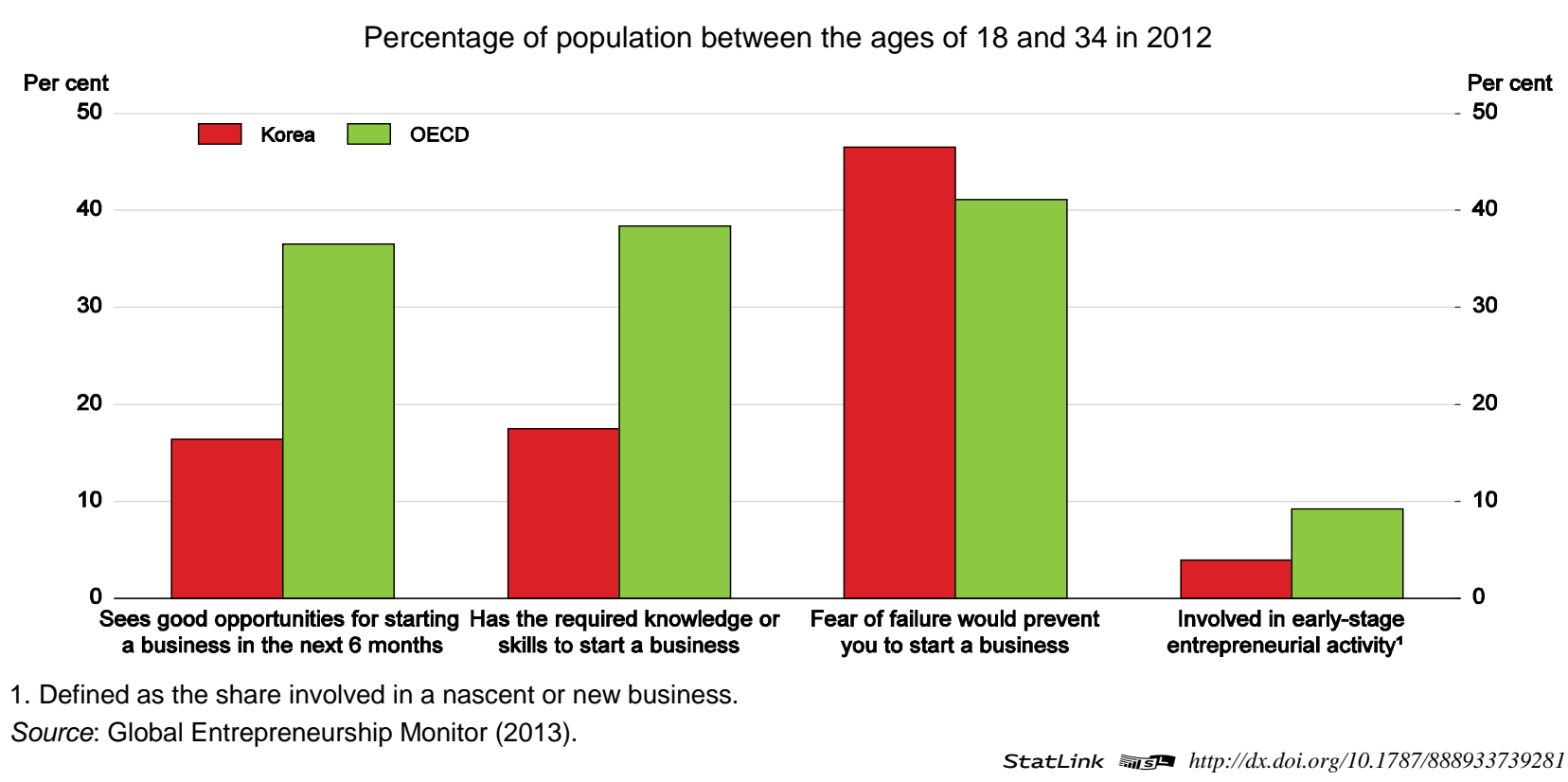

Second, the infrastructure for start-ups needs to be improved outside of the Seoul capital region. Surveys indicate that $77 \%$ of university students outside the capital region are very interested in starting a business, compared to only $25 \%$ of those inside the capital region (Lee et al., 2012). However, the entrepreneurial infrastructure as well as the human resources and education systems to mentor young entrepreneurs are concentrated in the capital region. In November 2017, the government announced that it would redesign the 19 Centres for Creative Economy and Innovation that have been established throughout the country as regional innovation hubs (Ministry of SMEs and Start-ups, 2017b), which should help reduce the infrastructure gap.

Third, it is important to reduce the risk of failure to encourage greater entrepreneurship, in part by facilitating second chances for entrepreneurs who have experienced failure. The average debt, including tax delinquency, borne by the head of a bankrupt firm in 2017 was KRW 356 million (USD 330 000). Helping failed entrepreneurs cope with the high debt is essential to ensuring second chances. In 2017, the government took some measures to reduce their debt burden (MOSF, 2017):

- Companies receiving loans have co-guarantors, who are responsible for the debt if the borrowers are unable to pay. The impact on the co-guarantors is one of the factors that make entrepreneurs avoid bankruptcy at all costs. The government has decided to abolish the requirement for coguarantees on loans by four public institutions in 2018.

- $\quad$ Failed entrepreneurs who re-start their company or accept employment will be forgiven tax arrears of less than KRW 30 million (USD 27 785).

- The monthly restriction on their spending is planned to be raised from KRW 1.5 million to KRW 1.8 million (USD 1 667).

\section{Measures to promote senior entrepreneurship}

As noted above, the early departure of employees from firms - before age 50 on average - prompts a large number to create small firms using their retirement allowance. Many of these "necessity-driven" startups have little capital and technology. The policies to encourage entrepreneurship by women and youth through education, training support and providing infrastructure should also be extended to older persons to 
help them succeed as entrepreneurs. Creating positive awareness of entrepreneurship as a late-career option could help remove negative bias against older persons, which acts as a potential barrier to senior entrepreneurship. It is also important to ensure that start-up financing schemes do not discriminate against older entrepreneurs (OECD and EU Commission, 2012).

\section{Policies to improve financing of SMEs and start-ups}

Small firms' access to credit is limited by their absence of collateral, short credit history and lack of expertise needed to produce financial statements. From the supply side, the small scale of lending involved may not compensate the cost of screening and monitoring, resulting in an information asymmetry. As a result, financial institutions attribute a high risk of default to borrowers, providing some justification for government intervention to overcome this market failure (Jones and Kim, 2014). Korea has responded with large-scale support for SMEs. First, public credit guarantees for SME lending amounted to 3.8\% of GDP in 2016, down from 4.1\% in 2014, but still the second highest in the OECD after Japan (Figure 4). Second, the government provides direct lending, amounting to KRW 4.5 trillion (0.3\% of GDP in 2016). In 2016, 68\% of loans requested by SMEs were authorised. Third, the government provides a range of subsidy programmes as discussed above. The size and number of public SME financing programmes is high by international standards (Koo et al., 2015).

With such government support, the financing situation for SMEs appears relatively strong. SMEs accounted for $79 \%$ of total business loans in 2016, a high share by international standards (OECD, 2018a). The gap between the average interest rate on loans to SMEs and large firms fell from 79 basis points in 2008 to 23 in 2016 (Figure 23). The financing gap - the shortage in funding to SMEs due to market failure - was estimated at KRW 28 trillion for firms less than ten years old in 2015 (Lee et al., 2015). This amounts to 5\% of total lending to SMEs. Another study that examined credit rationing in the SME loan market concluded that the probability of rationing was more than $80 \%$ in only $0.4 \%$ of firms over $2013-14$ (Lee and Lim, 2017). These studies cast doubt on the need for extensive public financing of SMEs.

Figure 23. The interest rate spread between large firms and SMEs has fallen

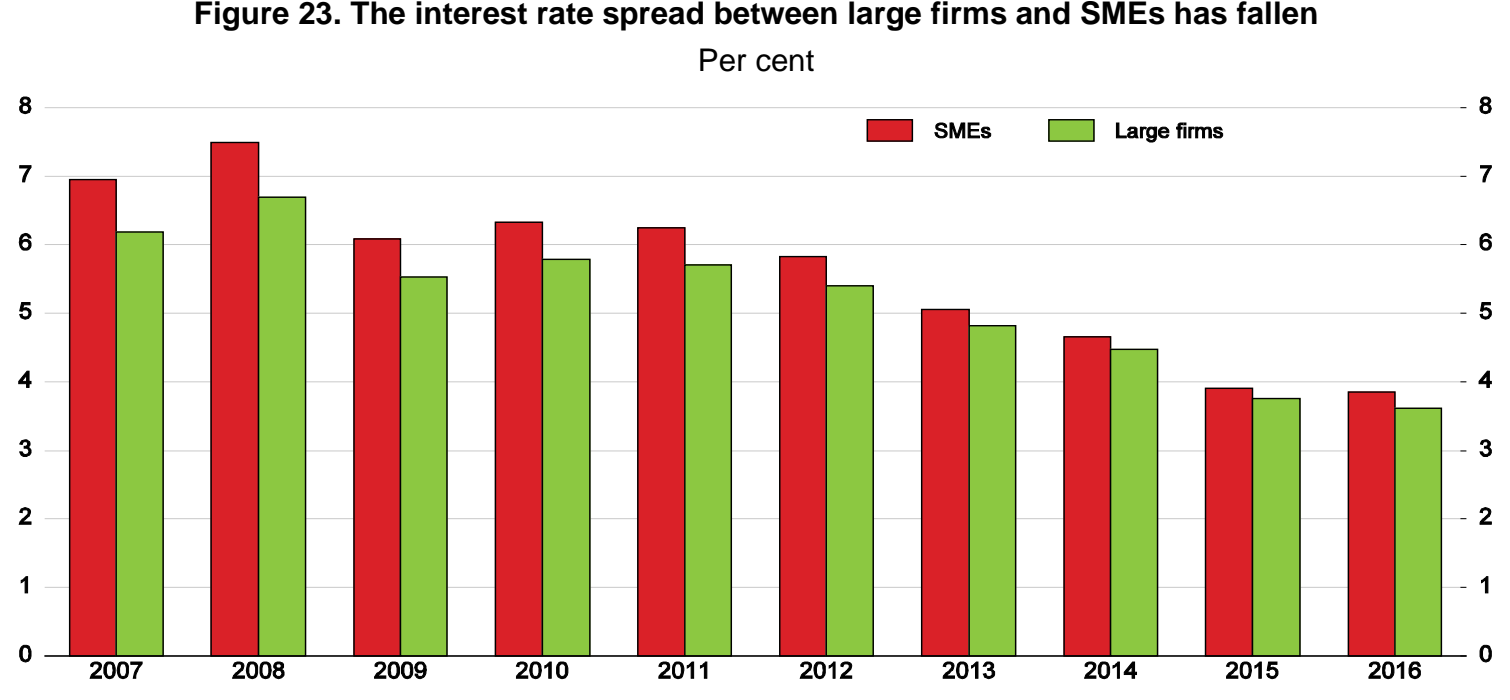

Source: OECD (2018a), Financing SMEs and Entrepreneurs 2018: An OECD Scorecard.

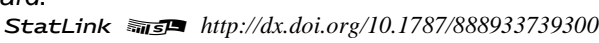

A study of 23 OECD and EU countries found that very few have undertaken rigorous studies of the economic costs and benefits of public support for SMEs through credit guarantees (OECD, 2017d). However, in Korea, current public programmes to support SME financing actually lowered the productivity of recipient firms and increased the survival probability of incompetent ones, according to recent evaluations by public think tanks (Chang et al., 2014; Cho et al., 2016; Chang, 2016a; Chang, 2016b). As a result, they have had a 
negative impact on the national economy. Once loans are given to a firm, credit guarantee providers and financial institutions share a common interest in its survival, as a default would result in losses for both of them. To delay or prevent such a loss, they may continue to support the firm, a phenomenon referred to as "evergreening", which facilitates the survival of non-viable firms. In 2016, 17\% of SMEs said that they had not covered interest costs for more than six months during the preceding three years. However, many SMEs are not audited and do not have reliable financial information.

Public support through direct credit and guarantees to SMEs has other adverse effects:

- It crowds out private funding and hinders the development of the market by reducing financial institutions' incentives to develop their credit evaluation and risk management skills for SME lending (Sohn and Kim, 2013).

- High and lasting government support discourages companies from expanding and thereby achieving economies of scale. The average age of firms in Korea that receive public guarantees on their loans is around 11 years and more than half of the guarantees were given to highly-rated companies.

This calls for: $i$ ) shifting the objective of SME policy from firm survival to productivity; ii) introducing a rigorous evaluation system based on appropriate performance indicators; and iii) restructuring policies to enhance efficiency based on such evaluations (Chang, 2016a).

In addition, a system of graduation from government financing support would reduce the share of support that only serves to extend the life of marginal companies (2016 OECD Economic Survey of Korea). Such a system would increase the emphasis on young firms, which face the largest the risk of market failure in obtaining financing. Indeed, the risk of credit rationing declines with a firm's age (Lee and Lim, 2017). Support for older firms crowds out support for start-ups and highly innovative young firms, which remain vulnerable. The survival rate of new start-ups after three years is relatively low in Korea at $41.0 \%$, compared to other countries such as Austria (62.8\%), the United States (57.6\%), Israel (55.4\%) and Italy (54.8\%) (Financial Services Commission, 2015). The 2015 initiative to reduce support for SMEs that are older than five years is a step in the right direction. In sum, SME programmes should shift from keeping non-viable companies alive to preventing market failures that bankrupt high-potential firms. Such a shift in policies would also facilitate a gradual decline in public support.

The "Integrated Management System for SMEs”, which was established in 2015, could provide the basis for a rigorous evaluation system based on appropriate performance indicators and a graduation programme. The System currently covers 689 programmes, whose cumulative assistance to small firms amounted to KRW 361 trillion (USD 334 billion) by April 2018. In addition, the System, which encompasses the support provided to 2.04 million SMEs since 2010, can reduce the number of SMEs benefitting from multiple programmes.

Lending for SMEs is typically based on direct government lending, public guarantees and collateral provided by the borrower, each with certain drawbacks. The government launched an initiative in 2014 to promote loans based on technology to provide greater financing for start-ups without collateral. Technology lending reached KRW 92.8 trillion (23.2\% of total loans to SMEs) at end-2016. However, technology finance is complicated given the high degree of information asymmetry due to the uncertainties inherent in technology development, private lenders' unfamiliarity with intangibles and the heterogeneous nature of the assets. Consequently, technology finance is increasingly reliant on public financial institutions (Brassell and Boschmans, 2018). Even so, public institutions provide low-risk financing to outstanding companies rather than lending to develop advanced technology associated with high risks, reflecting prudential regulations. This lowers the effectiveness of policy finance, while increasing the size of support. In short, public financing 
for technology focuses too much on existing firms wishing to expand using their current technology, rather than on start-ups with new technology.

Commercial banks tend to be reluctant to provide funds for start-ups that are technically strong but have poor profitability and financial stability and prefer to rely on collateral as a basis for lending. Such problems can be alleviated by the provision of more professional information on technology that can alleviate asymmetric information problems for start-up technology companies. However, banks have not invested enough to overcome this problem, which requires a high level of human capital. The biggest contribution that policy intervention can make is to help the market determine which company-owned intangible assets have realisable value (Brassell and Boschmans, 2018). To achieve this, the government created the Technical Credit Rating Agency in 2014. It has developed an integrated credit model, which combines credit evaluation and technology evaluation for innovative start-ups in the manufacturing sector. It should be broadened to cover the service sector.

Given the characteristics of technology finance, venture capital investment to finance high profit-high risk investment in technology would be appropriate. However, investment by business angels and venture capital firms amount to only $4 \%$ of total technology finance (Sohn, 2015). The technology finance ecosystem to encourage participation by private financial institutions and by venture capital firms is still at an early stage.

\section{Venture capital to promote innovative start-ups}

Venture capital investment in Korea, at $0.09 \%$ of GDP in 2016, was the fourth highest in the OECD and well above the average of $0.05 \%$ (Figure 24 ). Nevertheless, venture capital is a relatively minor source of SME financing, amounting to only $0.4 \%$ of loans to SMEs (OECD, 2018a). The public sector's share of venture capital investment fell from 49.3\% in 2013 to 33.1\% in June 2017, reflecting a large rise in privatesector activity (Table 7). This will facilitate the creation of venture capital funds that do not receive public funding and the accompanying government oversight. Venture capital funds based exclusively on privatesector funding would be able to operate autonomously and creatively, in contrast to the more cautious funds that include the public sector, which tend to avoid more risky, early-stage enterprises.

Table 7. The public sector's share of venture capital investment is falling but still high

Billion won and per cent

\begin{tabular}{|c|c|c|c|c|c|c|c|}
\hline & 2012 & 2013 & 2014 & 2015 & 2016 & June 2016 & June 2017 \\
\hline Public-sector investors ${ }^{1}$ & 429.3 & 822.3 & 1050.4 & 1114.7 & 1207.5 & 615.5 & 468.6 \\
\hline Share (\%) & 47.1 & 49.3 & 40.1 & 42.3 & 36.0 & 35.1 & 33.1 \\
\hline Private investors & 481.4 & 845.8 & 1569.1 & 1519.9 & 2144.0 & 1137.5 & 947.7 \\
\hline Total & 910.7 & 1668.1 & 2619.5 & 2634.6 & 3351.5 & 1753.0 & 1416.3 \\
\hline
\end{tabular}

1. The public sector includes central government ministries, local governments, the Korea Development Bank, growth ladder funds and public funds, including the National Pension Fund.

Source: Ministry of SMEs and Start-ups (2017d).

One result is that venture capital investment is not sufficiently focused on start-ups. Indeed, $63 \%$ of total venture capital in June 2017 was in firms more than three years old. Firms more than seven years old accounted for $32 \%$. The relatively small share invested in young firms reflects the absence of a secondary market and M\&As for investors to sell their shares and recover their investments. Consequently, they tend to rely on IPOs, which in 2016 took an average of 111/2 years on both the KOSDAQ and KONEX markets. Given that the average duration of venture capital funds is about seven years, they prefer to invest in relatively mature firms that are closer to an IPO. Recovery of their investment through M\&As, which is the most common method in the United States, accounted for only 3\% of the total in 2016 (Figure 25). Lowquality "over-the-counter sale and redemption" accounted for half of the total in 2016. 
Figure 24. Venture capital in Korea is among the highest in the OECD

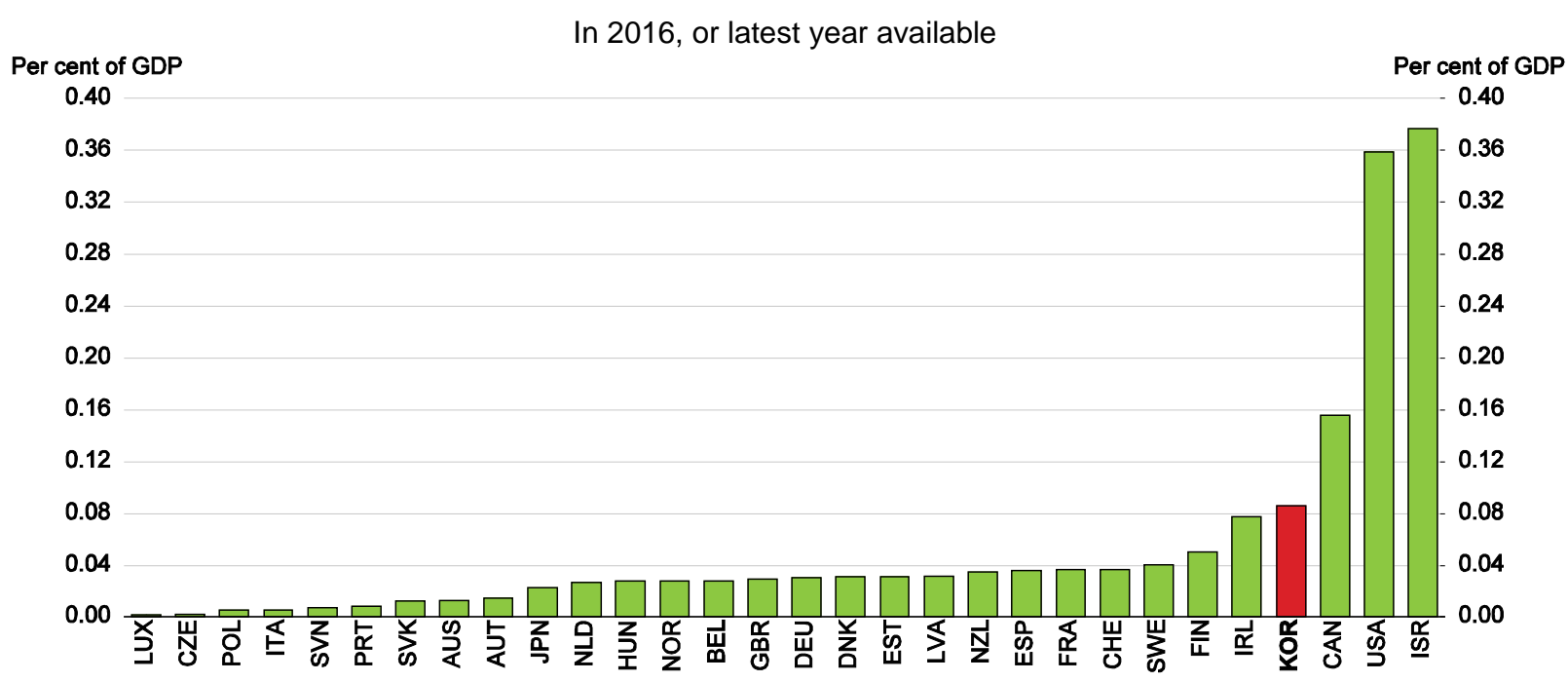

Source: OECD (2017c), OECD Entrepreneurship at a Glance 2017.

StatLink त्राजा http://dx.doi.org/10.1787/888933739319

Given that venture capital funds and angel investors are reluctant to invest in early-stage firms that carry high risk, due to the inactive M\&A market, reforms to activate it are necessary. The M\&A market in Korea remains small for a number of reasons. First, the heavy reliance of small firms on loans reduces their market potential. Second, business people avoid M\&As, which have long been associated with corporate bankruptcy procedures. Third, there is a lack of active participation of buyers such as private equity funds and strategic investors. Fourth, M\&A-related regulations constrain the market. The government's 2014 plan to revitalise the M\&A market by attracting potential buyers through mitigating investor regulations and restrictions on M\&A procedures should be pursued more vigorously. In addition, the tax benefit for M\&As aimed at acquiring technology should be maintained (2016 OECD Economic Survey of Korea).

Another objective is to expand investment by business angels. Although the amount of angel investment has rebounded since 2010, it is still 27\% below its peak in 2001 (Figure 26). The number of enterprises receiving investment from angels dropped from around 1000 in 2001 to 74 in 2011, before rebounding (Panel B). Angel investment as a share of adventure capital investment (angel investment plus investment by venture capital firms) is only about $7.5 \%$, compared to around half in many countries. Business angels play a crucial role at the early stage of start-ups, as it is difficult to judge the future of a company without access to internal information. The judgement of experienced angel investors, who can approach and evaluate internal information of start-ups as both investors and mentors, can attract venture capital funds, which would otherwise refrain from investing due to information asymmetries. To attract business angels, the government has cut the tax rate each year since 2012. In 2017, a 100\% tax deduction was provided for gains of less than KRW 15 million (USD 13 893) per person. 
Figure 25. The recovery of investment funds through M\&As is still low in Korea

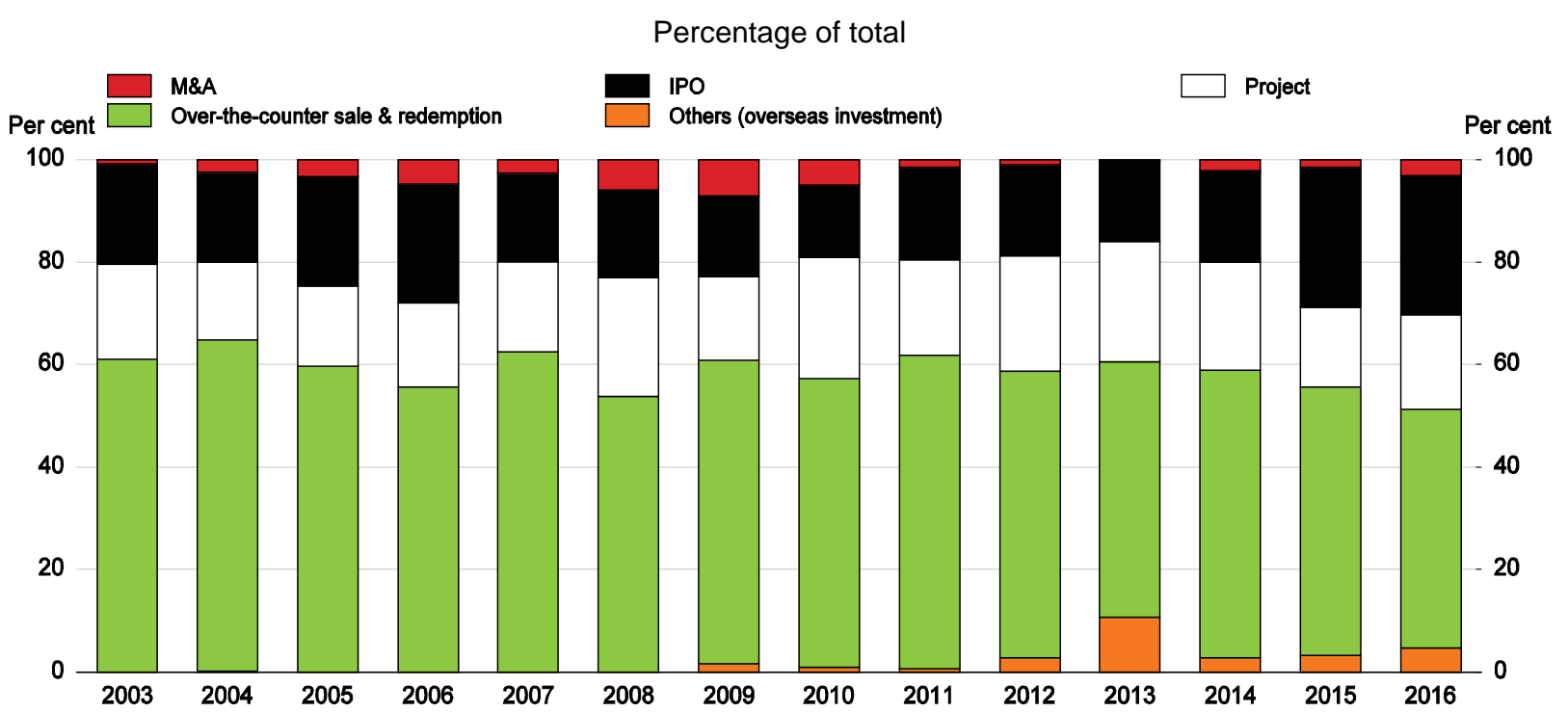

Source: Korea Venture Capital Association (2017), Korea Venture Capital Association Overview.

StatLink : तils http://dx.doi.org/10.1787/888933739338

Crowdfunding can provide new opportunities for SMEs that have not been able to obtain financing through traditional channels. Given that crowdfunding relies on the general public and takes place via the Internet, it is relatively cheap and fast, but has a high risk of fraud. A 2016 reform allows crowdfunding in the form of securities and loans. For securities, it is allowed for the commercialisation of ideas of start-ups, defined as unlisted companies within seven years of their creation. Non-professional individual investors can invest a maximum of KRW 2 million (USD 1 852) per firm. The maximum amount for crowdfunding per company was also limited to KRW 0.7 billion (USD 0.6 million) per year. As of March 2017, 14 securities firms were registered as financial intermediaries recognised by the Financial Services Commission in the Korea Securities Depository's CrowdNet website. The total amount of securities raised through crowdfunding increased from KRW 17.4 billion, amounting to $0.8 \%$ of venture capital investment in 2016, to KRW 27.8 billion (USD 25.7 million) in 2017. Loans provided through crowdfunding have increased more rapidly, reaching KRW 2.3 trillion (USD 2.1 billion) in 2017.

Figure 26. Investment by angel investors has rebounded but remains below earlier peaks
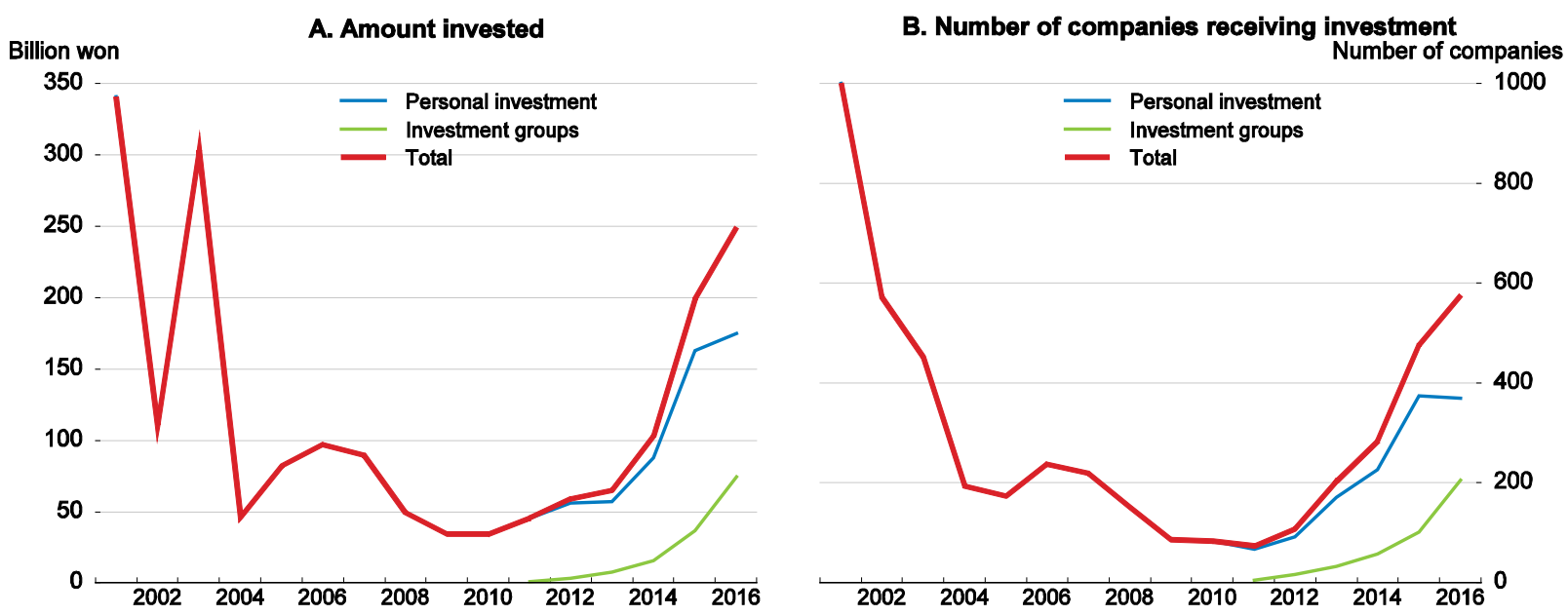

Source: Ministry of SMEs and Start-ups (2017a). 


\section{The Tech Incubator Programme for Start-ups (TIPS)}

Korea is developing business incubation centres that combine mentoring for start-ups and financial support. By 2016, Korea had 67 centres supporting 6655 companies, with a total budget of KRW 25 billion (USD 23.2 million). Around 80\% were located at universities and research centres, which made them useful for technology development and industry-academia cooperation. However, they were less proficient at providing business sector expertise.

The government launched the TIPS programme in 2014 to better combine technological development and business expertise. The programme, which is modelled on Israel's Technology Incubator (TI) (Box 5), is designed to induce angel investors to provide incubation and mentoring, which is combined with government R\&D (Figure 27). First, TIPS are led by the private sector. The private-sector angel investor invests KRW 100 million in the start-up and the government provides KRW 500 million (USD 463000 ) of R\&D funding. Second, TIPS allows for the failure of start-ups. Unlike in the past, failed firms do not have to reimburse the government for the R\&D funding. Third, TIPS provides funding, a workplace, incubating and mentoring together with the angel investment. In November 2017, the government announced a plan to select 20 innovative companies each year that have growth potential and to foster them in TIPS (MOSF, 2017). The main criteria for receiving public funding will not be whether the firm is an SME or its number of employees, but rather the company's age and business history. The government's priority is on start-ups given their success in creating jobs.

Figure 27. The operating process of TIPS

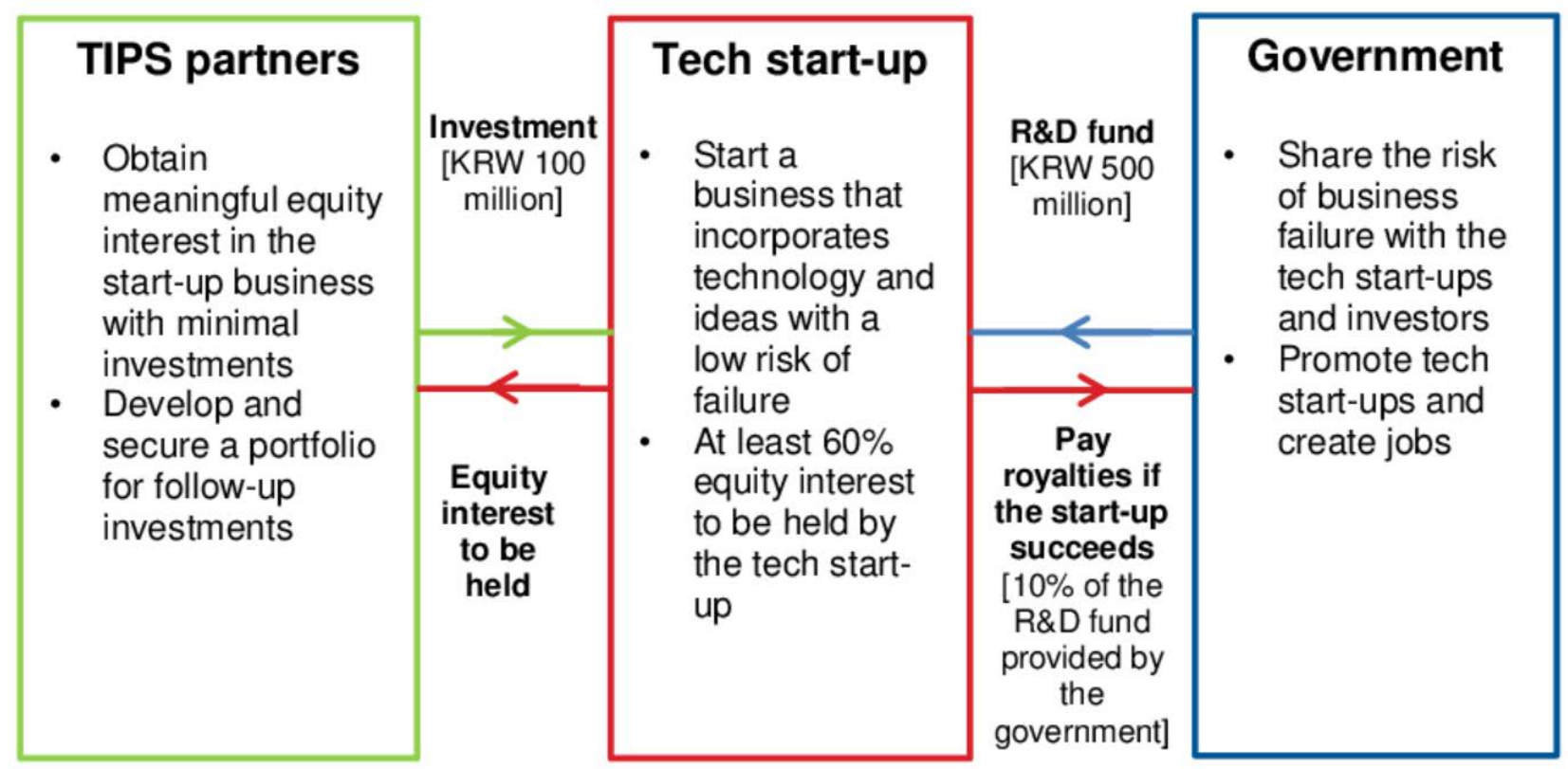

Source: TIPS Website, http://www.jointips.or.kr/about.php. 


\section{Box 5. Korea's Tech Incubator Programme for Start-ups is based on Israel's programme}

Korea's Business Incubator (BI) programme, introduced in 1998, had a number of difficulties. To provide better service for start-ups, Korea chose Israel's Technological Incubator (TI) programme as a model for its Tech Incubator Programme for Start-ups (TIPS), which was launched in 2014. Indeed, TIPS closely resembles the TI programme (Table 8), which has a number of positive features (Bae, 2013);

- The government, incubator operator and companies have strong incentives to participate in the TI programme. In the case of successful firms, the government can reinvest the royalties in new start-ups or in R\&D. Incubator operators can own $30 \%$ to $50 \%$ of the equity of a start-up by covering $15 \%$ of the total cost of the project. Companies benefit by having their expenses paid and have greater chance of success through the support and mentoring while avoiding financial or credit problems in the case of failure.

- $\quad$ TI projects focus primarily on high technology fields, such as medical devices, ICT and biotech, which can be commercialised quickly with a low investment cost, in contrast to general manufacturing industry.

- An evaluation committee composed of internal and external experts selects the participating companies through rigorous screening of their technical ideas. The experts evaluate the company's achievements relative to its plan and provide additional funds only when the key milestones are reached.

- The companies will receive up to USD 500000 for two years and will be connected to various private funds for support necessary to cross "Death Valley" (the time between when a start-up receives an initial capital injection until it starts generating revenues).

- The incubator operator, which used to be a public-sector institution but is now a private-sector entity, is differentiated according to field of specialisation.

Table 8. A comparison of Israel's TI programme with Korean incubator programmes

\begin{tabular}{|c|c|c|c|}
\hline $\begin{array}{l}\text { Year of } \\
\text { introduction }\end{array}$ & $\begin{array}{l}\text { BI (Korea) } \\
1998\end{array}$ & $\begin{array}{c}\text { TIPS (Korea) } \\
2014 \\
\end{array}$ & $\begin{array}{l}\text { TI (Israel) } \\
1991 \\
\end{array}$ \\
\hline $\begin{array}{l}\text { Government } \\
\text { budget }\end{array}$ & $\begin{array}{l}\text { Mainly for establishing } \mathrm{BI} \\
\text { centres }\end{array}$ & $\begin{array}{l}\text { Operating expenses and R\&D } \\
\text { funding }\end{array}$ & $\begin{array}{l}\text { Operating expenses and R\&D } \\
\text { funding }\end{array}$ \\
\hline $\begin{array}{l}\text { Operator selection } \\
\text { process }\end{array}$ & Government designated & $\begin{array}{l}\text { Open competition bidding } \\
\text { method }\end{array}$ & Open competition bidding method \\
\hline Major operator & Mainly universities (78.3\%) & $\begin{array}{l}\text { Consortium led by angel } \\
\text { investment companies }\end{array}$ & $\begin{array}{l}\text { Consortium led by venture } \\
\text { capitalists }\end{array}$ \\
\hline $\begin{array}{l}\text { Operator's } \\
\text { business period }\end{array}$ & 15 years & 6 years & 8 years \\
\hline $\begin{array}{l}\text { Equity interest } \\
\text { participation }\end{array}$ & No equity interest participation & $\begin{array}{l}\text { Equity interest participation up to } \\
30 \%\end{array}$ & $\begin{array}{l}\text { Equity interest participation up to } \\
550 \%\end{array}$ \\
\hline Target company & $\begin{array}{l}\text { Preparing entrepreneurs and } \\
\text { firms less than seven years old }\end{array}$ & $\begin{array}{l}\text { Preparing entrepreneurs and } \\
\text { firms less than seven years old }\end{array}$ & Preparing entrepreneurs \\
\hline Incubating period & Maximum 3 years & Maximum 3 years & Maximum 2 years \\
\hline $\begin{array}{l}\text { Incubating and } \\
\text { investment }\end{array}$ & $\begin{array}{l}\text { Separation of incubating } \\
\text { and investment }\end{array}$ & $\begin{array}{l}\text { Convergence of incubating and } \\
\text { investment }\end{array}$ & $\begin{array}{l}\text { Convergence of incubating } \\
\text { and investment }\end{array}$ \\
\hline $\begin{array}{l}\text { Repayment of } \\
\text { government grants } \\
\text { in case of success }\end{array}$ & No & $\begin{array}{l}\text { Pay } 10 \% \text { of R\&D fund provided } \\
\text { by the government as royalty }\end{array}$ & $\begin{array}{l}\text { Pay } 3 \% \text { of sales as contingency } \\
\text { fees }\end{array}$ \\
\hline
\end{tabular}

The success of TIPS depends on ensuring that public support contributes to productivity improvement of firms rather than extending the survival of marginal firms. As noted above, the productivity of firms receiving public funds is estimated to be less than that of firms that do not receive support. In addition, firms' survival probability two years after receiving funding from the government was higher than for firms that did not receive government funding. This suggests that government intervention in providing financing has undermined the efficiency of the market (Chang, 2016a). To avoid negative outcomes, support should focus on start-ups at an early age rather than mature firms. 


\section{Box 6. Recommendations to enhance dynamism in SMEs and entrepreneurship}

\section{Key recommendations}

- Introduce a comprehensive negative-list regulatory system.

- Allow firms in new technologies and new industries to test their products and business models without being subject to all existing legal requirements (i.e. a regulatory sandbox).

- Increase lending based on firms' technology by expanding public institutions that provide technological analysis to private lending institutions.

- Ensure that support provided to SMEs improves their productivity by carefully monitoring their performance and introducing a graduation system.

- Increase the quality and availability of vocational education to reduce labour market mismatch and labour shortages in SMEs.

\section{Further recommendations}

- $\quad$ Further tailor regulatory systems to company size while avoiding incentives that encourage SMEs to remain small.

- $\quad$ Reduce barriers to trade (including services) and foreign direct investment to strengthen product market competition and increase opportunities for SMEs to join global value chains.

- $\quad$ Make the R\&D tax credit more advantageous for small firms.

- Enhance labour market flexibility to make the use of digitalisation more effective for firms while expanding the social safety net.

- Improve the insolvency framework to reduce the personal costs for failed entrepreneurs, thereby raising Korea's low firm exit rate and encouraging the reallocation of resources to innovative firms.

- Help potential female entrepreneurs to balance work and family and obtain financing to reduce the large gender gap in entrepreneurship rates.

- $\quad$ Expand and improve entrepreneurship education at the primary and secondary level to improve the social image of entrepreneurship and develop entrepreneurial skills, attitudes and behaviours.

- Increase venture capital investment in early stage firms by activating the M\&A market by relaxing regulations and providing financial support to sellers.

\section{REFERENCES}

Adalet McGowan, M., D. Andrews and V. Millot (2017a), “The Walking Dead? Zombie Firms and Productivity Performance in OECD Countries”, OECD Economics Department Working Papers, No. 1372, OECD Publishing, Paris.

Adalet McGowan, M., D. Andrews and V. Millot (2017b), “Insolvency Regimes, Zombie Firms and Capital Reallocation”, OECD Economics Department Working Papers, No. 1399, OECD Publishing, Paris, http://dx.doi.org/10.1787/5a16beda-en.

Andrews, D., C. Criscuolo and Gal P. (2016), “The Best versus the Rest: The Global Productivity Slowdown, Divergence across Firms and the Role of Public Policy”, OECD Productivity Working Papers, 201605, OECD Publishing, Paris.

Andrews, D., G. Nicoletti and C. Timiliotis (2018), “Going Digital: What Detertmines Technology Diffusion Among Firms?” OECD Economics Department Working Papers, No. 1466, OECD Publishing, Paris. 
Association of High Potential Enterprises of Korea (2017), 2016 Survey of High Potential Enterprises, Seoul (in Korean).

Bae, Y. (2013), “Features and Implications of Israel's Technological Incubator Program”, Science and Technology Policy, Vol. 23, No. 2, Science and Technology Policy Institute, Seoul (in Korean).

Baumol, W. (2002), The Free-Market Innovation Machine: Analyzing the Growth Miracle of Capitalism, Princeton: Princeton University Press.

Brassell, M. and K. Boschmans (2018), "Fostering the Use of Intangibles to Strengthen SME Access to Finance”, OECD SME and Entrepreneurship Papers, No. 8, OECD Publishing, Paris.

Chang, H. and Y. Lee (2017), "Survey of the Actual Situation of the Competitiveness of Small and Mediumsized Export Companies in 2017”, Trade Focus, No. 32, Korea International Trade Association (KITA), Seoul (in Korean).

Chang, K. (2017), “Smart Factory Trends at Home and Abroad”, KB Knowledge Vitamin, Vol. 17, No. 37, Kookmin Bank Financial Group Ecomomic Research Institute, Seoul (in Korean).

Chang, W. (2016a), “Is Korea’s Public Funding for SMEs Achieving its Intended Goals?”, KDI Focus, No. 63, Korea Development Institute, Sejong.

Chang, W. (2016b), "Performance Evaluation and Improvement Direction of Financial Support for Start-up Small and Medium Businesses: Focusing on Policy Finance”, KDI Working Paper, Korea Development Institute, Sejong (in Korean).

Chang, W. (2017), “An Empirical Study on the Effects of Public Procurement on the Productivity and Survivability of SMEs: Case of the Korean Mining and Manufacturing Sectors", KDI Journal of Economic Policy, Vol. 39, No. 1, Korea Development Institute, Sejong.

Chang, W. (2018), "A Study on a Dynamic Fiscal Policy Evaluation System for Improving the Efficiency of Industrial and Corporate Fiscal Policy,” Korea Institute of Public Finance Research Paper (work in progress), Korea Institute of Public Finance, Sejong (in Korean).

Chang, W., S. Woo and Y. Yang (2014), “A Study on the Improvement of SME Support Policy (II)”, KDI Working Paper, No.2014-10, Korea Development Institute, Sejong (in Korean).

Chang, W. and S. Woo (2015), Performance Evaluation and Policy Task of SME Policy Finance Considering Vertical Relationship with Large Enterprises, Korea Development Institute, Sejong (in Korean).

Cho, D., H. Yang, G. Hong, and C. Han (2016), "Low Effectiveness Compared to SME Policy Utilization”, i-KIET Industrial Economic Issues, No.11, Korea Institute for Industrial Economics and Trade (KIET), Sejong (in Korean).

Cho, Y. and S. Kim (2013), "Zero Base Review of Small Business Regulations and Suggestions for Improvement”, KOSBI Basic Research Reports, No. 13-20, 13-21, Korea Small Business Institute, Seoul (in Korean).

Choi, S., S. Kwon and Y. Chang (2017), "Regulatory Innovation Direction of SMEs to Prepare for the Fourth Industrial Revolution Era”, SME Focus, Vol. 17, No. 15, Korea Small Business Institute (KOSBI), Seoul (in Korean).

Financial Services Commission (2015), "Building A New Guarantee System for SMEs”, Press Release (4 November), Seoul (in Korean).

Global Entrepreneurship Development Institute (2018), Global Entrepreneurship Index 2018.

Global Entrepreneurship Monitor and the Prince's Youth Business International (2013), Generation Entrepreneur? The State of Global Youth Entrepreneurship. 
Hong, W. and S. Hong (2017), "Implications of Statistical Analysis on the Trickle-Down Effect", SME Focus, No. 17-3, Korea Small Business Institute, Seoul (in Korean).

Jones, R. (2009), “Boosting Productivity in Korea's Service Sector”, OECD Economics Department Working Papers, No. 673, OECD Publishing, Paris, http://dx.doi.org/10.1787/226625875038.

Jones, R. and M. Kim (2014), "Promoting the Financing of SMEs and Start-ups in Korea”, OECD Economics Department Working Papers, No. 1162, OECD Publishing, Paris. http://dx.doi.org/10.1787/5jxx054bdlvh-en.

Jones, R. (2018), "Reforming the Large Business Groups to Promote Productivity and Inclusion in Korea”, OECD Economics Department Working Papers, OECD Publishing, Paris (forthcoming).

Jung, J. (2016), “Analysis of the Economic Effects of Corporate Regulation through the Application of a General Equilibrium Model”, KERI Insight, Vol. 16, No. 38, Korea Economic Research Institute, Seoul (in Korean).

Kim, H. (2017), "Problems and Improvement Plans of Small Business Taxation System”, KIPF Brief, Vol. 56, Korea Institute of Public Finance, Sejong (in Korean).

Kim, I., Y. Kim and Y. Park (2016), "Impact and Implication of Global GVCs on Corporate Productivity”, KIET Industrial Economic Analysis, No. 201704, Korea Institute for Industrial Economics and Trade (KIET), Sejong (in Korean).

Kim, Y. (2014), "Measures for Revitalizing Youth Employment: Focusing on Financial Support for Jobs and Revitalization of Start-ups", KDI Focus, No. 35, Korea Development Institute, Sejong (in Korean).

Kim, Y. (2015), “The Youth Labor Market in Korea: Current Situation and Employment Policy”, e-Labor News Issue Papers, No. 162, Korea Labor Institute, Sejong.

Koo, J., Y. Kim and S. Lee (2015), “A Study of Current SME Financing in Korea and Its Relationship with SMEs’ Financing Condition”, KIF Policy Research Papers, 2015-02, Korea Institute of Finance, Seoul (in Korean).

Korea Venture Capital Association (2017), Korea Venture Capital Association Overview, Seoul (in Korean).

Korea Women Entrepreneurs Association (2015), Survey on the Status of Female Enterprises in 2015, Seoul (in Korean).

Lee, J. and C. Choi (2017), "Reinventing the Government to Nourish Innovation Ecosystem”, KDI School Working Paper Series, 17-02, KDI School of Public Policy and Management, Sejong.

Lee, J. and H. Lim (2017), "Does Credit Rationing Really Exist in Korea? Evidence from the SME Loan Market”, Korea Journal of Financial Studies, Vol. 46, No. 3, Korean Securities Association, Seoul.

Lee, K., S. Woo and K. Bahn (2015), "A Study on the Estimation of SME Financing Gap and the Reallocation of Policy Funds”, Economic Development Research, Vol. 21, No. 2, Korea Development Economic Association, Seoul (in Korean).

Lee, Y., G. Jung, B. Jang, S. Kim, M. Lee, Y. Kim, S. Kim, W. Jung, and S. Lee (2012), "Vitalisation of Technology-based Start-ups by Inspiring Entrepreneurship”, STEPI Policy Research, No. 2012-11, Science and Technology Policy Institute, Seoul (in Korean).

Lee, Y., C. Han, S. Kim, and D. Lee (2017), “Global Start-ups are Performing Well Not Only in Exporting but also in Job Creation”, i-KIET Industrial Economic Issues, No. 31, Korea Institute for Industrial Economics and Trade (KIET), Sejong (in Korean).

Ministry of SMEs and Start-ups (2017a), “Angel Investment Also Stood out in Venture Capital Investment: Angel Investment Exceeded 200 Billion Won”, Press Release (3 August), Daejeon (in Korean). 
Ministry of SMEs and Start-ups (2017b), “Announcement of Plan to Create an Ecosystem for Innovative Start-ups”, Press Release (2 November), Daejeon (in Korean).

Ministry of SMEs and Start-ups (2017c), Promotion Plan for Female Business Activities, Daejeon (in Korean).

Ministry of SMEs and Start-ups (2017d), "Venture Capital Investment Market Continued to Boom during the First Half of 2017," Press Release (2 August), Daejeon (in Korean).

Ministry of SMEs and Start-ups (2018), 2017 Survey on the Status of Start-ups, Daejeon (in Korean).

Ministry of Strategy and Finance (2017), "Extended Ministerial Meeting on the Economy: Creating an Ecosystem to Nurture Innovative Start-ups”, Press Release, 2 November.

Moon, B. (2017), “Comparison Analysis of Job Creation and Innovation Capacity of Export and Domestic Companies: Focusing on Good Manufacturing Companies”, Trade Focus, No. 19, Korea International Trade Association (KITA), Seoul (in Korean).

Nikkei Asian Review (2017), “Japan’s First ‘Regulatory Sandboxes’ Could Open Next Spring”, 31 October, https://asia.nikkei.com/Politics-Economy/Policy-Politics/Japan-s-first-regulatory-sandboxes-couldopen-next-spring.

Noh, M. (2017), "Plan to Improve the Tax Support System for R\&D to Activate SMEs", SME Focus, No. 17-05, Korea Small Business Institute, Seoul (in Korean).

OECD (2009), Promoting Pro-Poor Growth: Employment, OECD Publishing, Paris.

OECD (2010), SMEs, Entrepreneurship and Innovation, OECD Publishing, Paris.

OECD (2013a), Skills Development and Training in SMEs, OECD Publishing, Paris.

OECD (2013b), The Survey of Adult Skills: Reader's Companion, OECD Publishing, Paris.

OECD (2014), OECD Economic Surveys of Korea, OECD Publishing, Paris.

OECD (2015a), Education at a Glance 2015, OECD Publishing, Paris.

OECD (2015b), OECD Science, Technology and Industry Scoreboard 2015, OECD Publishing, Paris.

OECD (2015c), Taxation of SMEs in OECD and G20 Countries, OECD Publishing, Paris.

OECD (2016a), "Economic and Social Benefits of Internet Openness", OECD Digital Economy Papers, No. 257, OECD Publishing, Paris, http://dx.doi.org/10.1787/5jlwqf2r97g5-en.

OECD (2016b), Entrepreneurship at a Glance 2016, OECD Publishing, Paris.

OECD (2016c), OECD Economic Outlook, No. 99, May, OECD Publishing, Paris.

OECD (2016d), OECD Economic Surveys of Korea, OECD Publishing, Paris.

OECD (2016e), OECD Science, Technology and Innovation Outlook: Country Profile -- Korea, OECD Publishing Paris.

OECD (2016f), The Korean Public Procurement Service: Innovating for Effectiveness, OECD Public Governance Reviews, OECD Publishing, Paris.

OECD (2017a), “Determinants of Digital Technology Use by Companies”, OECD Science, Technology and Innovation Policy Papers, No. 40, OECD Publishing, Paris.

OECD (2017b), Enhancing the Contributions of SMEs in a Global and Digitalised Economy, OECD Publishing, Paris.

OECD (2017c), Entrepreneurship at a Glance 2017, OECD Publishing, Paris. 
OECD (2017d), “Evaluating Publicly Supported Credit Guarantee Programmes for SMEs”, www.oecd.org/finance/Evaluating-Publicly-Supported-Credit-Guarantee-Programmes-forSMEs.pdf.

OECD (2017e), OECD Digital Economy Outlook 2017, OECD Publishing, Paris, http://dx.doi.org/10.1787/9789264276284-en.

OECD (2017f), OECD Science, Technology and Industry Scoreboard 2017, OECD Publishing, Paris.

OECD (2017g), Small, Medium, Strong: Trends in SME Performance and Business Conditions, OECD Publishing, Paris.

OECD (2017h), Regulatory Policy in Korea: Towards Better Regulation, OECD Reviews of Regulatory Reform, OECD Publishing, Paris.

OECD (2017i), “R\&D Tax Incentive Country Profiles 2016: Korea”, Measuring R\&D Tax Incentives, http://oecd/rdtax.

OECD (2018a), Financing SMEs and Entrepreneurs 2018, OECD Publishing, Paris.

OECD (2018b), OECD Economic Surveys of Korea, OECD Publishing, Paris.

OECD and EU Commission (2012), Policy Brief on Senior Entrepreneurship.

Office for Government Policy Coordination Prime Minister's Secretariat (OPM) (2017), "Promotion of New Government Regulatory Reform, Focusing on Innovation and Public Welfare", Press Release, 7 September (in Korean).

Park, H. (2017), "Evaluation of Korean Entrepreneurship Environment through International Comparison of Entrepreneurship Index”, KERI Brief, Vol. 17, No. 02, Korea Economic Research Institute, Seoul (in Korean).

Raina, S. (2016), “The Gender Gap in Startup Success Disappears When Women Fund Women”, Harvard Business Review, 19 July, https://hbr.org/2016/07/research-the-gender-gap-in-startup-successdisappears-when-women-fund-women.

Small and Medium Business Administration (2011), "Incubator Centres Re-organised into Advanced Third Generation Platform!”, Daejeon (in Korean).

Sohn, S. and D. Kim (2013), Tasks for the Development of SME Financing, Korea Institute of Finance, Seoul.

Sohn, S. (2015), “Challenges and Improvement Measures of Domestic Technology Finance”, Korea Institute of Finance, Seoul (in Korean).

Tech Incubator Programme for Start-ups (2018), TIPS website, http://www.jointips.or.kr (accessed 16 February 2018).

World Bank Group (2017), Doing Business 2018: Reforming to Create Jobs, Washington DC.

World Economic Forum (2017), Global Competitiveness Index 2017-18, Geneva, http://reports.weforum.org/global-competitiveness-index-2017-2018/. 